\title{
O REGIME JURÍDICO DA TAXA DE SERVIÇO PÚBLICO NO SISTEMA CONSTITUCIONAL BRASILEIRO*
}

\author{
Ricardo Pires Calciolari"
}

\begin{abstract}
Resumo:
O escopo principal do artigo é a análise das taxas coletadas em retribuição a prestação de serviços públicos específicos e divisiveis no Sistema Constitucional Tributário Brasileiro. Inicialmente, a temática é introduzida por um breve escorço histórico da evolução legal e doutrinária da taxa, especialmente nas Constituições brasileiras. Após, o descritor (hipótese) e o prescritor (conseqüência) da norma tributária foram examinados, levando em conta a aplicabilidade do princípio da capacidade contributiva e da extrafiscalidade. Por fím, fez-sc uma análise mais apurada do serviço público e de suas caracteristicas de especificidade e divisibilidade, concluindo acerca da temática abordada.
\end{abstract}

Palavras-chave: Taxa de serviço público. Sistema Constitucional Tributário brasileiro. Regra-matriz de incidência da taxa.

\begin{abstract}
:
The main scope of the article is the analysis of the fees, here realized as a tax collected as retribution to the public, specific and divisible services in Brazilian Constitutional Tax System. First of all, we have done a study of the historical evolution of the fees in the doctrine and in the law, taking above all the Brazilian Constitutions. Next, the tax norm's describers (hypothesis) and prescribers (consequence) were examined, taking into account the applicability of the ability to pay principle and the economic use of taxes. Ultimately, the divisibility and specificity as characters of public services were scrutinized, bringing some conclusions about this theme.
\end{abstract}

Keywords: Fees (taxes collected as retribution to the public, specific and divisible services). Brazilian Constitutional Tax System. Tax norm.

\footnotetext{
A presente análise é fruto dos estudos realizados na elaboração da Tese de Láurea intitulada "Taxas e Preços Públicos no Sistema Constitucional", apresentada no ano de 2004, perante o Departamento de Direito Econòmico e Financeiro da Faculdade de Direito da Universidade São Paulo c uma das vencedoras do prêmio de melhores Teses de Laurea de 2004 do respectivo departamento. A consecuçào deste trabalho seria impossivel sem o auxilio inestimável do orientador professor doutor José Maurício Conti, a quem devem ser atribuidos parte dos acertos, já os erros são imputáveis somente ao autor.

- Aluno do Curso de Pós-Graduação stricto sensu da Faculdade de Direito da Universidade de São Paulo, na área de Direito da Seguridade Social, sob orientação do professor associado Doutor Marcus Orione Gonçalves Correia. perante o Departamento de Direito do Trabalho e da Seguridade Social.
} 


\section{Introdução}

Historicamente, as taxas tem sido utilizadas para dar ensejo a figuras exacionais diversas, possibilitando uma série de abusos. com o escopo de garantir maior arrecadação para cobrir gastos estatais sempre crescentes. Asseverando que o regramento de qualquer figura tributária deve balizar-se principalmente pela Constituição, verifica-se uma norma ampla, o que traz a necessidade de uma interpretação cautelosa no intuito de afastar tais abusos históricos.

As taxas são comumente classificadas pela doutrina em dois grandes grupos: (i) taxas de poder de polícia e; (ii) taxas de serviço público. Aquelas são cobradas em virtude do exercício de poder de polícia e ustas em razão de serviço público, específico e divisível prestados ao contribuinte ou postos a sua distribuição, de acordo com o art. 145, inciso II, da Constituição Federal.

Enquadrando-se determinada situação ao constitucionalmente previsto como taxa. poderá o legislador propor norma instituindo o tributo. Tal exação ficará sob a égide do regime de direito tributário, arcando. contribuinte e administração, com os ônus e benesses deste regime.

Não obstante, o Estado, mais propriamente a partir da terceira década do século XX, assume participação cada vez mais ativa na economia e vida social, atuando, inclusive, em áreas que antes eram tipicamente privadas. Assim, receitas oriundas da participação do Estado no mercado passam a integrar os cofres públicos.

Neste sentido, muito se discutiu se a participação do Estado na sociedade, prestando serviços, daria ensejo a taxa ou a preço público, perquirindo-se qual seria o verdadeiro conteúdo jurídico do adjetivo "público" que precede a palavra serviço na norma constitucional.

Atualmente a situação se inverte. O Estado tende. por motivos diversos, relegar parcela de sua participação social a entes privados, participando de forma menos ativa na atividade industrial e econômica. Deixa de ser um Estado atuante para se tornar um Estado regulador e fiscalizador.

Tal nuance traz conseqüências brutais. Serviços anteriormente prestados pclo Estado serão prestados pelos particulares. A questão, agora com novas variáveis, é retomada, e sua relevância prática cresce ainda mais.

Assim, partimos ao estudo da taxa de serviços, do seu modelo legal e de sua correta delimitação no regime jurídico tributário, tendo em mente o mandamento constitucional. Deste modo, após um breve histórico, iniciamos a análise desta figura 
dentro do sistema tributário nacional, expondo as diferenças e pontos de confluência entre esta e as demais figuras jurídicas tributárias.

\section{A partir desta análise, passamos então a separar os elementos componentes} da norma que engendra a figura tributária. Sopesados os elementos, expusemos as interações entre tais elementos e a conseqüência destas interações no regime jurídico da figura. Nesse sentido, um elemento primordial i a delimitação jurídica do signifícado da expressão "serviço público", qual o seu alcance e sua área de atuação. O que propomos ao longo deste trabalho é estabelecer um critério teórico válido para a análise de situações fáticas.

\section{Breve escorço histórico}

O nascimento dos tributos confunde-se com o surgimento do próprio Estado, já que eles representam um dos fundamentais sustentáculos para o regular funcionamento da máquina estatal. ${ }^{\prime} \mathrm{Na}$ Antiga Grécia a tributação já era discutida ${ }^{2}$ e no Império Romano fixou-se a distinção entre impostos diretos e indiretos. ${ }^{3}$ Do período

Sobre a temática: "Antes de ter entrado para o direito público a concepção do Estado de Direito (Rechtsstar), a imposição tributária decorria do poder de fato do soberano, manifestava-se na tributação uma simples relação de poder (Gewaltverhälnis) e não se podia falar da existência de um direiıo tributário. Mas desde o momento em que o Estado foi submetido ao direito, o tributo transformou-se em uma relação juridica (Rechtsverhältnis) pois o tributo só passou a ter existência quando legislado e portanto somente nos termos do direito objetivo". NOGUEIRA, Ruy Barbosa. Da interpretação e da aplicação das leis tributárias. 2. ed. São Paulo: Revista dos Tribunais, 1965. p. 95.

2 As mais remotas fontes remontam aos anos de 430 ou 445-352 a.C., nos escritos de Xenofonte sobre os empréstimos e rendas de Atenas e de suas minas de prata com o objetivo de tributar a exploração da atividade mineira por braço escravo como meio de alimentar os pobres. XENOFONTE. Les Revenus. Cyropédie, Hipparque etc. Paris, 1994. Apud: BALI:EIRO, Aliomar. Uma Introdução à Ciência das Fianças. 5. ed. Rio de Janeiro: Forense, 1968. p.26.

No Império Romano já havia a cobrança distinta de impostos diretos e indiretos, sendo que os primeiros recaiam sobre as pessoas e os indiretos oncravam bens como terras, heranças, manumissōes, litigios, entre outros. Dentre os impostos diretos podemos elencar a capilatio humana, que incidia diretamente sobre as pessoas. Salienta Silvio Meira que tal imposto era "a grande sobrecarga que o patriciado lançava sobre a classe menos venturosa, e que deu notivo a tantas convulsões sociais durante a República. Sustentavam assim, os plebeus, muitos exageros e caprichos da política avassaladora dos romanos". Como tributos indiretos existentes no Império Romano podenos destacar a vicesima hereditarium, a vicesima manumissionum e o venalitium, que incidiam, respectivamente sobre a herança ou legado, sobre a alforria do escravo e sobre os bens de consumo. Interessante destacarmos nesta época os tributos incidentes sobre o uso das latrinas ou mictórios públicos. Acerca deste tributo salienta o romanista: "Lê-se, em Suetônio. biografando Vespasiano, 23: "Censurou-lhe suu filho Tito por ter criado um imposto sobre a urina. Vespasiano. juntando-lhe ao nariz a primeira moeda recebida pelo novo tributo, interrogou-o "se se sentia incomodado com seu cheiro' Tito respondeu-lhe que não. Sem cmbargo, retrucout-lhe o imperador: 'Provém da urina ". Apesar do conceito da taxa surgir na doutrina somente muito tempo depois, já podemos ver aqui um tributo recebido cumo cuntrapresação de um serviço público prestado pelo Império, talvez possamos até arriscar em dizer ser uma taxa em forma embrionária. Confrontar: MIIRA. Silvio. Direito Tribulário Romano. São Paulo: Revista dos Tribunais, 1978. p. 11. 
correspondente à Idade Média destacam-se São Tomás de Aquino ${ }^{4}$ e Mauro Palmicri. ${ }^{5}$ Tambím a Revolução Francesa trouxe suas contribuições para o Direito Tributário. ${ }^{6}$

Contudo, só em meados do século XVIII inicia-se a teorizar uma diferenciação entre as diversas ispécies tributárias. ${ }^{7}$ A bem da verdade, mais precisamente no início do século XIX, começou-se a delinear de forma mais marcante a figura tributária aqui posta em relevo. Kurt Heinrich Rau, em 1832, țria prestado valorosa contribuição nestes termos. Tal autor elaborou uma teoria cientifica da taxa, analisando os aspectos conceituais, a natureza juridica e o fundamento das taxas, tomando, ademais, o cuidado de distingui-la dos impostos. Assim, em sua obra intitulada Principios de Ciência das Finanças, tal autor definiu, de forma resumida, a espécie taxa como sendo uma contraprestação de serviço essencial do Estado, vinculada a um interesse público. ${ }^{8}$

O próprio vocábulo "taxa" " na literatura fiscal, fazendária e tributária brasileira. foi utilizado historicamente para designar entes diversos, como alíquotas fiscais, direitos, contribuições específicas e até preços públicos. Não houve precisão terminológica, nem tampouco o cuidado necessário para designar os termos. podendo tal

1 Afirmara ser possivel a tributação em caso de escassez das rendas patrimoniais dos principes, bem como aconselhava que determinada quantia fosse reservada. com o objetivo de ser utilizada em casos supervenientes. Ubservar: BALEEIRU, Aliomar. Uma Introdução à Ciência das lïianças. 5. ed. Rio de Janeiro: Forense, 1968. p. 26.

5 Néste mesmo periodo histórıco Mauro Palmieri defendcu a proporcionalidade dos tributos contra os critérios progressivos ensaiados pela república flurentina. BALEEIRO, Aliomar. Uma Introdução à Ciência das Fianças. 5. ed. Rio de Janeiro: Forense, 1968. p. 26.

6 Acerca deste tema salienta Sabine M.A.: "The seventeenth century was a period of fiscal as well as political revolution. When it began the king had his proprietory and feudal revenues, an antique stereotype system of direct taxation still regarde as extraordinary, and customs duty on goods" E acresce ainda: "The "Glorious Revulution", in fiscal terms, buried prerogative as an inexhaustible treasury of arbitrary taxation: it also, reinforced by current fiscal thought, tended to favour a taxation system which spared the land, but, by the same token, not the poor". A Shorl History of Taxation. London: Butterworths, 1980. p. 97-98.

7 Neste sentido, salienta Aliomar Baleeiro: "Se bem que Von Justi e Adam Smith já houvessem notado, desdo o lim do século XVIII, a diferença entre certos tributos sobre todos os individuos e outros que só atingiam os usuários de determinado serviço, só no meado do século passado a distinção passou a ser assinalada pelos tratadistas, dando-se metodicament:, pelo menos no campo da doutrina. nomes especiais àqueles dois grupos tributários". BALEI:IRO, Aliomar. Parecer. Revista de direilo Administrativo, n. 34, p. 416.

\& Observar: MORAES, Bemardo Ribeiro de. A Taxa no Sistema Tributario Brasileiro. São Paulo: Revista dus Tribunais, 1968, p. 8. Flávio Bauer Novelli (Revista de Direiro Administrativo, n. 189, jul./set., 1992, p. 4.) cita outros que tambím contribuiram para a melhor delineação deste figura exacional: PUGLIESE. Le lasse nilla scienza e nel Diritı Positivo llaliano. Pádua: CEDAM, p. 3, 1930: GlANNINI, Achille D. II Concetto Giuridico di Tassa. Rivista Italiana di Diritlo Finanziario, v. I, p. 7, 1937. Confonme explicita em: Apontamentos sobre o Conceito Juridico de Taxa. Revista de Direlto Administrativo, n. 189. p. 4. jul./set., 1992.

9 Em portuguès taxa, para os espanhós lasa, para os franceses laux, para os italianos tassa, para os americanos fee, para os mexicanos derecho, para os alemāes gehuhr. 
vocábulo apresentar, de acordo com o contexto em que se encontrava, diversas significações absolutamente distintas. ${ }^{10}$

De fato, o Brasil, como também outros países, demoruu em acolher o conceito de taxa em sua legislação tributária." Somente na República, a Constituição Federal de 24 de fevereiro de 1891 instituiu uma discriminação das rendas da União, Estados e Municípios (arts. $7^{\circ}$ e $9^{\circ}$ ), atribuindo às unidades políticas, além dos impostos, as Taxas de Selo e a Taxa de Correios e Telégrafos (nos mesmos artigos anteriormente citados), não obstante permitisse a criação de novos tributos. Não havia ainda uma distinção entre taxas e impostos, ambos institutos eram utilizados de forma indiscriminada.

A Constituição Federal de 16 de julho de 1934 foi a que inaugurou em nosso ordenamento a distinção entru impostos e taxas, adotando a divisão bipartida dos tributos. Assim, distribuiu entre os diversos entes politicos competência para que impostos e taxas fossem cobrados. Tal Constituição utilizava como método distintivo o fato de que as taxas eram destinadas a compensar ou retribuir serviço público federal (art. $6^{\circ}$. inciso II), estadual (art. $8^{\circ}$ inciso II) e municipal (art. $13, \S 2^{\circ}$, inciso V) prestados ao contribuinte.

Posteriormente, a Constituição Federal de 10 de novembro de 1937, em seu art. 28, manteve a divisão bipartida dos tributos e foi sob sua égide que erigiu o primeiro conccito legal de taxa. Pelos idos de 1939, figuras fiscais esdrúxulas eram cobradas sob a errônea alcunha de taxa, daí a necessidade de se criar um conceito legal para esta espície de tributo. ${ }^{12}$ O Decreto-Lei n. 1.804, de 24 de novembro de 1939, ${ }^{13}$ estabeleceu a conceituação de taxa e imposto da forma que se segue:

10 "Mas. se o dircito tributário é. ainda hoje. sem dúvida mais que outros ramos do direito, uma disciplina carregada de problemas (nem todos, é certo, verdadeiros), seguramente não poderia constituir dentro dele uma exceção, uma ilha de tranqüilidade e de certeza, essa importante porte dele. que forma a teoria da taxa". NOVELLI. Flávio Bauer. Apontamentos sobre o Conceito Jurídico de Taxa. Revislu de Direito Administrativo, v. 189, p. 4, jul./set. 1992.

1 Durante o periodo Colonial (de 1500 a 1815), de Reino Unido (de 1815 a 1822) e no Império (de 1822 a 1889) a legislação vigente não fazia qualquer distinção entre os tributos. O sistema fiscal aplicado apresentava pouca ou nenhuma racionalidade. A tributação apresentava-se onerosa, com a incidència de inúmuros tributos (quinto das pedras e dos metais preciosos, dizima dos pescados e das colheitas de todos os produtos da terra, da redizima dos frutos da terra, da vintena do produto das especiarias, emolumentos, entre outros). Observar: MORAES, Bernardo Ribeiro de. A Taxa no Sislema Tribulário Brasileiro. São Paulu: Revista dos Tribunais, 1968. p. 8. Sobre esta época histórica. Amaro Cavalcanti asseverou que o Império sc extinguiu sem ter criado um sistema tributário que distribuísse conscientemente a arrecadação de acordo com as condiçðes econômicas do pais e que dividisse razoavelmente a reccita geral do Império e as reccitas particulares das províncias. Elementos de Finanças. Rio de Janeiro: Imprensa Nacional, 1896. p. 232.

12 Acerca do tema, salienta Bernardo Ribeiro de Morais: "Várias figuras fiscais esdrúxulas, desnaturadas e estranhas eram impostas às pessoas, sem a menor atenção ao conceito exato do tributo que estamos examinando" E ainda, para confirmar a necessidade existente à época de se formular um conceito legal de taxa, exemplifica: "Taxa de Caridade (Taxa de Assistência, Taxa de Assistència aos Mendigos ou Taxa de 


\section{Parte Segunda}

\section{Normas Orçamentárias}

XIX - A designação de imposto fica reservada para os tributos destinados a atender indistintamente às necessidades de ordem geral da administração pública; a de taxa, para os tributos exigidos como remuneração de serviços especificos prestados ao contribuinte ou postos à sua disposição, ou ainda contribuição para custear atividades especiais provocadas por conveniências de caráter geral ou de determinados grupos.

Pouco depois, edilou-se o Decreto-Lei n. 2.416 de 17 de julho de $1940,{ }^{14}$ o qual manteve a divisão bipartida estabelecida pela Constituição de 1937, afirmando ainda:

\section{Artigo $1^{\circ}$ omissis}

$\S 2^{\circ} \mathrm{A}$ designação de imposto fica reservada para os tributos destinados a atender indistintamente às necessidades de ordem geral da administração pública; a de taxa, para os exigidos como remuneração de serviços especificos prestados ao contribuinte, ou postos à sua disposição, ou ainda para as contribuiçōes destinadas ao custeio de atividades especiais do Fstado ou do Município, provocadas por conveniências de caráter geral ou de determinados grupos de pessoas.

Essa primeira definição legal de taxa mostra-nos alguns pontos importantes para o nosso estudo: (i) manteve-se a divisão bipartida de tributos somente admitindo-se impostos e taxas - de forma que as contribuições de melhoria e outras contribuições não se caracterizavam como figuras autônomas, permanccendo como subespécies de taxa; (ii) possibilitava, em parte, a distinção da taxa do preço público, visto que agora havia uma

Assistência Social), Taxa Hospitalar (Taxa de Assistência Hospitalar ou Taxa para fins Hospitalares), Taxa de Bombeiros (Taxa de Incêndio, Taxa para Manutenção de Serviço contra Incêndio), Taxa de Vigilância, Taxa de Guarda Noturna. Taxa de Hospedagem. Emolumentos. etc." A Taxa no Sistema Tributário Brasileiro. São Paulo: Revista dos Tribunais, 1968. p. 12-13.

13 Acompanhando as resoluçōes votadas na "I Conferência Nacional de Técnicos em Contabilidade Pública e Assuntos Fazendários", reunida de 5 a 31 de outubro de 1939. Nesta conferência Inácio Filho e Ubaldo Lôbo recomendaram que a legislação liscal deveria adotar a designação de taxa para "todos os demais tributos. isto $\dot{e}$, para os que são exigidos como remuneração por serviços específicos prestados ao contribuinte para custear atividades especiais provocadas por conveniências de caráter geral ou de determinadas classes" Anais da l Conferéncia de Técnicos em Contabilidade Pública é Assuntos Fuzendários. Rio de Janeiro: Ministerio da Fazenda, 1940. p. 303.

is Acompanhando. desta feita, as resoluções da "Il Conferència de Técnicos em Contabilidade Pública e Assuntos Fazendários", realizada de 14 de maio a 4 de junho de 1940. Ainda acerca deste Decreto-Lei, Gilberto Ulhôa Canto negara sua constitucionalidade, pois de acordo com a Constituição de 1937, tal norma não poderia ter sido editada pelo Presidente enquanto o Parlamento Nacional estivesse reunido, violando o disposto no art. 180 da Carta Magna untão um vigor. Temas de Direilo Tributário. Rio de Janeiro: Editora Alba. 1964. v. III, p. 55-60. 
definição tributária para esta espécie; (iii) definiu que as taxas seriam cobradas ou como remuneração por serviços específicos prestados ou postos à disposição do contribuinte ou como remuneração para custeio de atividades especiais do Estado, provocadas por conveniência de caráter geral ou por conveniência de determinado grupo de pessoas; (iv) distinguiu a taxa do imposto tendo em vista o produto da arrecadação, pois a taxa custearia atividades especiais do Estado. ${ }^{15}$

Vemos aqui uma conceituação abrangente. Conforme salienta o próprio $\S 2^{\circ}$ do art. $1^{\circ}$ do Decreto-Lei n. $2.416 / 1940$, scria possível a exigência de taxas para o custeio de atividades especiais do Estado ou do Município, provocadas por conveniências de caráter geral ou de determinado grupo de pessoas. ${ }^{16}$ Muitos criticaram este aspecto abrangente do conceito de taxa, o que possibilitaria a cobrança de impostos com destinação específica como se taxas fossem. Do modo como fora posto, tributo poderia ser cobrado de grupos diversos daqueles beneficiados com a vantagem. pois sequer havia referência à pessoa do contribuinte legalmente obrigado ao seu pagamento, o que propiciava abusos perigosos. ${ }^{17}$

Ademais, a tentativa de diferenciação entre impostos e taxas através da destinação do produto da arrecadação era por demais falha. Dentre os críticos do DecretoLei n. 2.416/1940 podemos elencar Ruy de Souza, ${ }^{18}$ Evaristo Garcia, ${ }^{19}$ Rubens Gomes de

is Bernardo Ribeiro de Morais ainda salienta que tal definição "apresentou, pela primeira vez, uma definição de imposto e de taxa, as únicas espécies tributárias então existentes" A Taxa no Sistema Tributário Brasileiro. São Paulo: Revista dos Tribunais, 1968. p. 15.

I6 Tal definição estranha de taxa, segundo Affonso Almiro (o qual teria atuado como Secretário da "II Conferência de Técnicos em Contabilidade Pública e Assuntos Fazendários"), "resultou de uma situação de fato. Os Estados e Municipios, por seus representantes - Secretários de Fazenda, Prefeitos, Diretores reunidos em Conferência. impuseram aquela definição porque, não fosse ela aceita, muitos Estado e Municípios teriam sua receita diminuída de percentagens elevadas e, em alguns casos, alarmantes. Então a norma, a lei, veio consagrar uma conceituação por todos conhecida como eivada de imperficiçōes, porém, necessária, no momento, para garantir uma situação de fato". Normas Gerais de Direiro Financeiro. Rio de Janeiro: Instituto Brasileiro de Direito Financeiro, 1950. p. 33-34.

1- Deste modo permitia-se cobrar Taxa para Indigentc, Taxa para Hospital ou mesmo Taxa di Estatisticas de grupos pessoas não ligadas aos serviços oferecidos, jả que tais serviços eram divisiveis e provocados por grupos sociais.

18 Para tal autor a taxa seria "uma espécie tão elástica em sua aplicação, que supera todas as tentativas teóricas para colocá-la em sólido campo juridico, objetivamente estruturado". Ciência das Finanças. Belo Horizonte: Faculdade de Direito da Universidade de Minas Gerais, 1953. p. 210-211.

19 Tal tributo "cai no regime das cousas elásticas, pois permite que, à sua sombra, sejam convocados para o pagamento grupos sociais diversos daqueles que se beneficiam com a vantagem, como foi notado, com acerto, no dossier organizado para a Conferência Nacional de Legislaçäo Tributária, pela Secretaria do Conselho Técnico de Economia e Finanças do Ministério da Fazenda". A Taxa nos Sistemas Triburários dos Municipios. São Paulo: edição do autor. 1943. p. 96. 
Sousa, ${ }^{20}$ Amilcar de Araújo Falcão, ${ }^{21}$ Gilberto Ulhôa Canto, ${ }^{22}$ Aliumar Baleeiro. ${ }^{23}$ Fábio Fanucchi, ${ }^{24}$ entre outros.

A Constituição de 18 de setembro de 1946 veio inaugurar em nossa legislação a divisão tripartida dos tributos, dividindo-os $\mathrm{cm}$ impostos, taxas e contribuições de melhoria $\mathrm{em}$ seu art. 30. Porém, tal Estatuto não estabeleceu diferenciações nem conceitos entre tais espécies, mantendo-se assim ainda válida a definição fixada pelo Decreto-lei n. 2.416/1940, que deveria ser interpretado de forma condizente com o novo texto constitucional.

Deste modo, as espécies tributárias passaram a ser imposto, taxa e contribuição de melhoria. Esta última apresentava-se como figura fiscal autônoma, contudo as demais contribuições eram arrecadadas como subespécies de taxa.

\section{E, sob a égide desta Constituição, erigiu-se o anteprojeto de Código} Tributário Nacional. ${ }^{25}$ Mostrava-se inovador para época e, especificamente sobre esta matéria, definiu que o destino da arrecadação não se enquadraria como elemento diferenciador das espécies tributárias, assim, a taxa não estaria subordinada ao custeio e serviço estatal, conforme transcrevemos:

Art. 47. São taxas os tributos destinados a remunerar serviços públicos específicos e divisíveis prestados ao contribuinte ou postos à sua disposição, cobrados exclusivamente das pessoas que se utilizem ou beneficiem,

20. Seria preciso ainda "acrescentar-lhe uma referência à pessoa do contribuinte legalmente obrigado ao seu pagamento, de modo a circunscrever o âmbito de sua aplicabilidade unicamente às pessoas que estejam $\mathrm{em}$ relação de causa e efeito com o serviço ou atividade do Estado que a taxa se destina a remunerar". Instifuição de Normas Financeiras para a União, os Estados e os Municipios. São Paulo: Centro das Indústrias e da Federação das Indústrias do Estado de São Paulo, p. 20.

21 Salienta: "a destinação não distingue os dois tributos, não só porque não constitui critério juridico, como porque existe uma classe de impostos os impostos ligados ou impostos com destinação determinada, cuja arrecadação é vinculada à receita de certo serviço" Introdução ao Direito Triburário. Rio de Janeiro: Edições Financeiras, 1959. p. 151.

$\because \quad$ "A definição de tributos contida no Decreto-Lei n. 2.416 , evidentemente a conceituação de taxa que se encontra no $\$ 2 .^{\circ}$ do art. $1 .^{\circ}$ das normas cuja codificação aquele Decreto-lei aprovou, não pode prevalecer, porque levaria, se accita. a confurdir essa espécie tributária com o imposto, confusão que é, como se mostrou, incompativel com o regime constitucional brasileiro" Acrescentando ainda: "o critério definicional, mesmo que se abstraiam outras objeções de monta ao esquema adotado pelo Decreto-Lei $n$. 2.416, não merece acolhimento, porque abandona a natureza especifica do lato gerador para fixar-se apenas no emprego que terá o produto da arrecadação do tributo" Temas de Direilo Tributário. Rio de Janeiro: Editora Alba, 1964. p. 59-65.

23 Afirmava tal autor nảo ser taxa, mas imposto com aplicações especiais os tributos destinados ao custeio de atividades especiais do Estado ou do Municipio, provocadas por convenicncias de caráter geral ou de determinados grupos de pessoas. Uima Introdução à Ciência das Fianças. 5. ed. Rio de Janeiro: Forense, 1968. p. 214.

24 Reforma Constitucional Tributária. São Paulo: Iditora Allas, 1966. p. 81.

25 Projeto de Lei n. 4.834, de 1954, sob o comando de Rubens Gomes de Souza c outros especialistas na matéría. 
efetiva ou potencialmente, do serviço que constitua o fundamento da sua instituição.

Não só o conceito de taxa, mas também os do imposto (art. 22) e da contribuição de melhoria (art. 49) eram mais rígidos e mais claros do que os estabelecidos pelo Decreto-Lei n. 2.416 e mais adequados ao que dispunha a divisão constitucional de tributos. $^{26}$

Tal definição legal exigia o nexo de causalidade entre a percepção do tributo taxa e o recebimento de uma vantagem ou provocação de uma despesa do Estado. No entanto, esta conceituação manteve-se apenas no anteprojeto e a tentativa de convertêla em lei não obteve êxito.

Assim, sem uma conceituação legal oportuna e conveniente, abusos e oportunismos fiscais foram mantidos (conforme já salientamos), agora agravados pela nova separação tripartida de tributos. ${ }^{27}$ Neste sentido, eram constantes as discussões nos tribunais acerca do enquadramento tributário de certas espécies.

Como a taxa apresentava-se como uma dos maiores instrumentos de violação das regras de discriminação constitucional de rendas e em virtude dos altíssimos indices de inflação presentes no ano de 1964, preocupou-se o Governo em redigir um projeto de emenda constitucional no sentido de reformular o sistema tributário ${ }^{28}$

Assim, promulgou-se em $1^{\circ}$ de dezembro de 1965 da Emenda Constitucional n. 18, que dispunha:

\begin{abstract}
Art. 18. Compete à União, os Estados, ao Distrito Federal e aos Municípios, no âmbito de suas respectivas atribuiçõus, cobrar taxas em função do exercicio regular do poder de polícia, ou pela utilização, efetiva ou potencial, de serviços públicos específicos e divisíveis prestados ao contribuinte ou postus à sua disposição.
\end{abstract}

26 Sobre o tema, esclarcce o autor do anteprojeto, Rubens Gomes de Souza: "A conceituação de taxa reveste-se de excepcional importância jurídica: sendo rigidas e nominais as atribuições de competência quanto aos imposto (Constituição, arts. 15, 19 e 20), mas necessariamente genérica a mesma atribuição quanto às taxas (Constituição, art. 30, inciso II), fornecem estas o terruno mais propicio à evasão das limitações constitucionais que cerceiam a atividade do legislador tributário. através da instituição de autènticos impostos formalmente caracterizados como taxas". Comissão Especial do Código Tributário Nacional. Trabalhos da Comissão Especial do Código Tributário Vacional. Rio de Janciro: Ministério da Fazenda, 1954. p. $158-159$.

27 Salienta Bernardo Ribeiro de Morais: "Decorridos 25 anos do momento da instituição do conceito legal de imposto e taxa, nada fora alteradu. Na prática, a legislação fiscal do País continuava instituindo taxas originais, absurdas no seu sentido técnico, ımbora com destinação específica do produto da artıcadação. eram exigidas de terceiros. sem relação alguma com a pessoa do verdadeiro bencficiárin do serviço público". A Taxa no Sistema Tributário Brasileiro. São Paulo: Rcvista dos Tribunais, 1968. p. 24.

28 Veste sentido, salienta Rubens Gomes de Souza que fora uma tentativa para "trancar essa porta á fraude". $U$ Novo Sistema Tribulário Nacional. São Paulo: Associação dos Advogados de São Paulo. 1967. p. 9. 
Além de trazer um conceito legal de taxa, fez o mesmo com as contribuições de melhoria (art. 19), dispensando uma conceituação para os impostos. Cumpre observarmos que o sistıma tributário manteve a divisão tripartida de tributos e, com relação à taxa, ela poderia ser arrecada, a partir de agora, não-só pela prestação de serviços públicos, mas também pela atuação do poder de polícia. Ademais, a partir de agora a cobrança de taxa só poderia ser justificada com a prestação de serviços "específicos e divisiveis" e não somente serviços "prestados" pelo Estado (como queria o Decreto-lei n. 2.416). ${ }^{29}$

Após a aprovação desta Emenda Constitucional, eis que surge o diploma complementar da reforma tributária, tornando-se a Lei n. 5.172, de 25 de outubro de 1966. a qual receberia posteriormente sua denominação atual de Código Tributário Nacional. ${ }^{30}$ Tal Lei definiu adotou também a divisão tripartida dos tributos, além de conceituar imposto (art. 16), contribuição de melhoria (art. 81) e taxa (art. 77), sendo esta da seguinte forma:

Art. 77. As taxas cobradas pela União, pelos Estados, pelo Distrito Federal ou pelos Municipios, no âmbito de suas respectivas atribuições, têm como fato gerador o exercício do poder de polícia. ou a utilização efetiva ou potencial, de serviço público específico e divisível, prestado ao contribuinte ou posto à sua disposição.

Assim, o Código Tributário Nacional acompanhou fielmente os dizeres tributários então vigentes perante a Constituição Federal de 1946 e pelas alterações trazidas pela Emenda Constitucional n. 18 de 1965.

Não-obstante, logo depois veio a surgir nova Constituição, promulgada em 24 de janeiro de 1967, ratificando os novos conceitos. Esta Constituição manteve a divisão tripartida dos tributos, dispondo em seu bojo:

Artigo 19. Compete à União, aos Estados, ao Distrito Federal e aos Municipios, arrecadar:

29 Tal conceito seria "rigido o bastante para não comportar desvirtuamento. e, por outro lado, suficientemente compreensivo para não entravar a atuação legitima do governo". SOU7 A, Rubens Gomes de [et al]. O Novo Sistema Tributário Nacional. Sảo Paulo: Associaçào dos Advogados de São Paulo, 1967. p. 9.

30 "Como se vê. a Lei 5.172/1966 foi redigida sob a égide da Constituição FederaV/1946, respeitando o seu art. $5^{\circ}, \mathrm{XV}$, 'b'. tendo sido recepcionado pelo $\$ 10$ do art. 18 da Constituição/1967, o qual dispunha: 'Lei complementar estabelecerá normas de Direito Tributário, disporá sobre conflitos de competència nessa matéria entre União, os Estados, o Disırito Federal e os Municípios e regulará as limitação constitucionais ao poder de tributar' Em seguida, o Ato Complementar n. 36, de 13/03/1967. em decorrência dos efeitos de recepção e reconhecendo naquela lei as funções de lei complementar, atribuiu-lhe a denominação com a qual atualmente a reconhecemos, de Código Trihutário Nacional' TÔRRE.S. Heleno 'laveira. Funções das leis complementares no sistema tributário nacional - hierarquia de normas - papel do Código Tributário Nacional no ordenamento. Revista de Direiro Tributario, n. 84. 
I os impostus previstos nesta Constituição;

II taxas pelo excrcicio regular do poder de polícia ou pela utilização de serviços públicos, prestados ao contribuintc ou postos à sua disposição;

II] contribuição de melhoria dos proprietários de imóveis valorizados pelas obras públicas que os beneficiaram.

Esta Magna Carta houve por bem dispensar a conceituação legal de imposto, mas de fato nada inovou, trazendo em seu bojo o já anteriormente previsto na Emenda Constitucional n. 18 de 969 e no Código Tributário Nacional.

Posteriormente, a Constituição da República Federativa do Brasil, publicada em 05 de outubro de 1988, trouxe a previsão:

Art. 145. A União. os Estados, o Distrito Federal c os Municipios poderão instituir os seguintes tributos:

I impostos;

II taxas, em razão do exercício do poder de polícia ou pela utilização efetiva ou potencial, de serviços públicos específicos e divisíveis, prestados ao contribuinte ou postos a sua disposição:

III contribuição de melhoria, decorrente de obras públicas.

$\S 1^{\circ}$ Ornissis

$\S 2^{\circ}$ As taxas não poderão ter base de cálculo de impostos.

Manteve, em quase sua totalidade, as linhas da Constituição anterior, contudo, dispôs expressamente a impossibilidade de estabelecerem-se taxas com base de cálculo idênticas às de imposto.

\section{A taxa de serviço}

\subsection{A taxa no regime de classificação constitucional dos tributos}

Salienta Fduardo Garcia Maynez que "classificar es un problema de perspectiva" e ainda acresce que "las clasificaciones tienen unicamente valor cuando responden a exigencias de orden prático o a necesidades sistemáticas" " De fato, as classificações apresentam-se sempre como úteis ou inúteis. vantajosas ou desvantajosas, de acordo com sua praticidade ou com o interesse do intérprete. ${ }^{32}$ Não-obstante, as

31 Intoducción al estidio del derecho. 18. ed. México: Ed. Porrua, 1971. p. 78.

32 Também acerca das classificações: "las clasificaciones no son ni verdaderas ni falsas, son serviciales o inutiles; sus ventajas o desventajas están supeditadas al interés que guia a quien las formula, y a su 
classificações também não ficam imunes à visão ideológica do intérprete, pois a atividade de classificar exige muitas das vezes um embate de caráter ideológico, uma valoração de valores. $^{33}$

Neste sentido, as primeiras classificações acerca das espécies tributárias tinham como base a despesa pública, classificação esta de cunho eminentemente financista, pautadas no relacionamento entre despesas e receitas.

Num momento posterior surge a doutrina da glorificação do fato gerador. ${ }^{34}$ E neste bojo surge a doutrina de Achille Donato Giannini. formulando a distinção entre tributos vinculados e não vinculados a uma atuação estatal. Assim. afirmava o italiano que "no nosso ordenamento juridico, como, de resto, no de outros Estados, a distinção entre impostos e taxas é incerta e oscilante (...) constituindo duas espécies de um mesmo gênero, têm uma estreitíssima afinidade juridica entre si e com os tributos especiais" 35 Deste modo, os tributos que não tivessem qualquer relação com alguma atuação estatal específica dirigida ao contribuinte seriam impostos, e, de outro lado, os tributos vinculados a esta atuação estatal seriam as taxas, formulando-se a visão bipartida dos tributos.

Esta doutrina estrangeira encontrou eco em âmbito nacional. Renomados tributaristas da época, como Dino Jarach, Rubens Gomes de Souza, Aliomar Baleeiro, Amílcar de Araújo Falcão e Ruy Barbosa Nogueira seguiram este entendimento.

Nosso CTN, erigido sob esta ótica doutrinária adotou, a posição tripartida. seguindo os dizerem da Constituição então vigente. Deste modo. expressou, no seu art. 16 que "imposto é o tributo cuja obrigação tem por fato gerador uma situação independente de qualquer atividade estatal especifica, relativa ao contribuinte" e mais adiante, nos arts. 77 e 81, estabeleceu a necessidade de vinculação com uma atividade especifica estatal quc resultasse, respectivamente, num serviço público ou exercicio regular do poder de polícia e valorização imobiliária.

facundidad para presentar un campo de conocimiento de una manera más facilmente comprensible. más rica em consecuencias prácticas deseables. (...) Decidirse por una classificación es más bien como optar por el sistema métrico decimal frente al sistema de medición de los ingleses. Si el primero es preferible al segundo no es porque aquél sea verdadero y este falso. sino purque el primero es más cômodo, más fácil de manejas más apto para satisfazer con menor esfuerzo ciertas necesidades o conveniencias humanas" (ARRIO), Genaro. Votas sobre derecho y lenguaje. Buenos Aires: Abeledo-Perrot. 1972. p. 72-73. FERRAZ JR., T'ércio Sampaio. Função Social da Dogmática Jurídica. São Paulo: Max Limonad, 1998.

34 Aqui se apregoava que, existente no mundo fático um evento passivel de tributação. criada estaria a relação juridica tributària e, conseqüentemente, o crédito tributário.

35 GIANNINI. Achille Donato. I concetti fondamentali del Diritlo Tributário. Turim: UET, 1956. p. 98-106. Observar também. neste sentido, do mesıno autor: Istituzioni di Dirilto Tributario. 8. ed. Milano: Giuffrè, 1960. 
Posteriormente, Becker analisou o tributo como típica espécie de norma jurídica, tendo como base as teorias de Kelsen e Pontes de Miranda, buscando, na estrutura da norma, elementos que de fato poderiam atuar como critérios para uma adequada classificação dos tributos. Deste modo, os elementos adequados a serem adotados como critérios seriam, de forma predominante. a base de cálculo e. de forma secundária, o critério material da hipótese de incidência. Assim, concluiu o autor que os tributos seriam impostos ou taxas a depender da designação semântica da base de cálculo, sendo impostos os tributos. cuja base de cálculo expressasse um fato lícito qualquer e taxas os tributos cuja base de cálculo representasse o preço pago por uma atuação estatal. $^{36}$

Mais tarde, contribuiu para o tema de forma grandiosa, Geraldo Ataliba, tomando como base a construção de Becker para criar a hipótese de incidência tributária. Afirmava assim ser a hipótese de incidência tributária a descrição genérica e abstrata de um fato, descrita pela lei, de forma hipotética, prévia, ${ }^{37}$ a qual continha aspectos (a saber, pessoal, material, temporal e espacial).$^{38}$ Este autor então, antes de proceder à análise do critério classificatório, salientou:

O próprio sistema constitucional adota uma classificação dos tributos e faz derivarem conseqüências do discernimento que estabelece entre as espécies e subespécies tributárias. Isto é: o texto constitucional consagra uma determinada classificação e atribui regimes jurídicos diferentes a serem aplicados às espécies tributárias. ${ }^{30}$

Esta observação é pertinente. Qualquer critério classificatório a ser adotado deve seguir o caminho da legalidade, da exegese da norma, caso contrário, a classificação será, por conseqüência óbvia. inválida ou inútil para o jurista exegeta, por ser ilegal. E não basta seguir o mero caminho da lei, deve-se analisar, primeiramente, os dispositivos constitucionais e verificar o que neles fora disposto. ${ }^{40}$

36 BECKER, Alfredo Augusto. Teoria Geral do Direilo Tribulário. 3. ed., São Paulo: Lejus, 1999. p. 365-380.

37 Para o autor: "É, enfim, categoria, arcuétipo, protótipo, förmula que fixa conceito operacional de ampla validade. com alcance lato e abrangente de parte essencial da realidade juridica", e mais adiante "mero conceito, necussariamente abstrato. É formado pelo legislador fazendo abstração de qualquer fato concreto. Por isso é mera 'previsão legal'”. ATALIBA, Geraldo. Hipólese de Incidência Tributária. 6. ed. São Paulo: Malheiros, 2001. p. 58-60.

"São, pois, aspectos da hipótese de incidência as qualidades que esta tem de determinar hipoteticamente os sujeitos da obrigação tributária, bem como seu conteúdo substancial, local e momento de nascimento. Dai designarmos os aspectos essenciais da hipótese de incidência tributária por: a) aspecto pessoal; b) aspecto material; c) aspecto temporal e d) aspecto espacial". AT.ILIBA, Geraldo. Hipórese de Incidencia Triburaria. 6. ed. São Paulo: Malheiros. 2001. p. 78.

40 O critério classificatório deve ser sempre juridico. excluindo-se quaisquer influências externas, como noções ou formulações impertinentes, de origem econômico-financeira ou pré-jurídica. "As definiçōes jurídicas 
Esclarecidos os pressupostos, Ataliba, seguindo a linha de Giannini, esclarece que o critério jurídico de classificação dos tributos está na consistência do aspecto material da hipótese de incidência normativa. Explica o autor:

Examinando-se e comparando-se todas as legislações existentes - quanto à hipótese de incidência - verificamos que, em todos os casos, o seu aspecto material, das duas uma: a) ou consiste numa atividade do poder público (ou numa repercussão desta) ou, pulo contrário, b) consiste num fato ou aconlecimento inteiramente indiferente a qualquer atividade estatal. ${ }^{41}$

Assim. os tributos serão vinculados ou não-vinculados a uma atividade do poder público e, procedendo deste modo, os impostos seriam tributos não vinculados, enquanto as taxas e as contribuições de melhoria seriam tributos vinculados.

Contudo, a atuação estatal, componente diferenciador, seria diversa nas taxas ¿ nas contribuições. "Nas taxas a hipótcse de incidência é uma atuação estatal diretamente (imediatamente) referida ao obrigado (pessoa yue vai ser posta como sujeito passivo da relação obrigacional que tem a taxa por objeto)" enquanto na contribuição "ou se tem uma atuação estatal que produz um efeito, o qual (efeito) se ionecta com alguém (que é, pela lei, posta na posição de sujeito passivo), ou, pelo contrário, se tem uma pessoa (que afinal será sujeito passivo) que desenvolve uma atividade, ou causa uma situação que requer, exige, provoca ou desencadeia uma atuação estatar" 42

Deste modo, a atuação estatal nas taxas é diretamente dirigida ao contribuinte (ou imediata, como quer Ataliba), enquanto que nas contribuições de melhoria ela é dirigida indiretamente ao contribuinte (ou mediatamente). Assim, quando o contribuinte aufere serviço público específico e divisível ou quando provoca a atuação do poder de polícia, há uma vinculação direta com a atuação estatal. De forma diversa, nas contribuições deve haver a autuação estatal, mas também a conseqüência desta atuação, que é a valorização imobiliária decorrente da construção de obra pública, no caso das

devem tomar por ponto de partida o dado juridico supremo: a lei constitucional. A partir do desenho constitucional dos tributos é que se deve construir o seu conceito; deve ater-se cxclusivamente aos aspectos normativos. constitucionalmente prestigiados. Por isso procuramos evitar postura não dogmática, informada por critérios pré-juridicos, de grande valia para o legislador, mas secundários para o jurista, que tem como ponto de partida de sua tarefa exegética o texto normativo". Acrescenta ainda que é "despropositado, anticientifico e absurdo o jurista recorrer a qualquer critério năo juridico, pré-juridico ou metajurídicos, para estabelecer uma classificação juridica dos institutos que estuda. Não é lícito ultrapassar os limites do fenômeno que se põe como objeto do nosso estudo: o direito positivo".ATALIBA, Geraldo. Hipótese de Incidencia Tributária. 6. ed., São Paulo: Malheiros, 2001, p. 125-126 e 128. Sobre este aspecto: "os critérios financeiros são certos no plano pré-jurídico. No plano juridico são inserviveis e imprestáveis" BECKER, Alfredo Augusto. Teoria Geral do Direito Tributário. 3. ed., São Paulo: Lejus, 1999.

4 AT ALIBA, Geraldo. Hipótese de Incidència Tributária. 6. ed. São Paulo: Malheiros, 2001 . p. 130.

42 Id., ibid., p. 147. 
contribuições de melhoria. Daí dizer-se que a referibilidade ao obrigado é direta ou imediata nas taxas e indireta ou mediata no caso das contribuições. ${ }^{43}$

Dando seqüência às inovações, Paulo de Barros Carvalho, lcvando em conta o já dito por Bccker e Ataliba, cria a Regra-Matriz de Incidência. ${ }^{44}$ Para tal autor a norma de direito tributário traria, no seu antecedente (hipótese de incidência) três critérios (a saher, material, temporal e espacial), e no seu conseqüente (através da relação lógica se A então deve ser B), os critérios subjetivos (sujeito ativo e sujeito passivo) e cuantitativas (base de cálculo e aliquota). Deste modo. o descritor (descrição de um fato abstrato) contido no critério material da hipótese de incidència (antecedente normativo) deveria se relacionar com o conseqüente quantitativo. base de cálculo, unindo o já preconizado por Ataliba e Becker.

Através deste raciocínio, conclui com o mesmo critério de Ataliba que as taxa se identificam como um pagamento em virtude de uma atuação estatal direta. ${ }^{45}$ Ademais, dentro de sua teoria, o critério material da hipótese de incidência scria então a atividade estatal direta (materializada através ou du serviço público especifico e divisível ou do efetivo exercício de poder de policia). ('ontudo, coerente com sua doutrina, afirma que o respectivo critério material deverá manter relação com o conseqüente quantitativo. Deste modo, a base de cálculo deverá exprimir, nas taxas, a intensidade da participação estatal. Caso isto não ocorra. o legislador terá instituido outro tributo, diverso, irrelevante seu nomem iuris.

43 Explicita o autor: "Duas caracteristicas, portanto, estremam a taxa da contribuição: 1) É que, na taxa, basta a atuação $\square$. como aspecto material da h.i. Na contribuição. requer-se atuação $\square$ + efeito (valorização) A. 2) Por outro lado, a referibilidade entre a atuação $\square$ e o obrigado $O$ - como dito - é direta, na taxa, e indireta (mediante sua consequèencia 4.) na contribuição. Daí o contraste entre os gráficos expressivos da taxa e da contribuição:

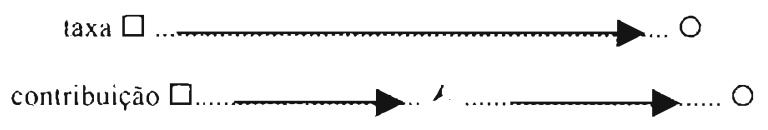

Quando se trata de taxa, há direta conexão (referibilidade) entre a atuação $\square$ e o obrigado O; h.i. da taxa é só a atuação. Quando se trata de contribuição, a conexão entre a atuação e o ubrigado é indireta; se faz mediante a circunstância especifica da valorizaçio que medeia entre ambos, como fato necessário" Idem ibidem. p. 149.

CARV ALHO, Paulo de Barros. Teoria da Norma Tribuliria. 3. ed., São Paulo: Max Limonad, 1998. p. 200.

4 "Taxas são tributos que se caracterizam por apresentarcm, na hipótese da norma, a descrição de um fato revelador de uma atividade estatal. direta e especificadamente dirigida ao contribuinte. Nisso diferem dos impostos, e a análise de suas bases de cálculo deverá exibir, forçosamente. a medida da intensidade da participação do Estado. Acaso o legislador mencione a existência de taxa, mas eleja base de cálculo mensuradora de fato estranho a qualquer atividade do Poder Público, então a espécie tributária será outra, naturalmente um imposto". CARVALHO. Paulo de Barros. ('urso de Direito Tributário. 14. ed. São Paulo: Saraiva, 2002. p. 38-39. 
Ademais, salienta este autor que as espécies tributárias seriam três: (i) impostos; (ii) taxas, e; (iii) contribuições de melhoria. Como em Ataliba, Paulo de Barros separa os tributos em vinculados e não-vinculados, sendo impostos os não vinculados, e as taxas e contribuições de melhoria os vinculados (no primeiro caso imediatamente e no segundo mediatamente). Vemos aqui um diferencial entre as classificações de Paulo de $\operatorname{Barros}^{46}$ e Ataliba, para aquele as contribuições (exceto as de melhoria) serão ou impostos ou taxas, de acordo com o formato da sua Regra-Matriz.

Diversas classificações têm sido propostas atualmente, o que nos mostra que o tema classificação constitucional dos tributos é matéria bastante discutida na nossa doutrina c também na jurisprudência. Ives Gandra da Silva Martins classifica os tributos em impostos, taxas, contribuições de melhoria, contribuições especiais e empréstimos compulsórios. $^{47}$ Já Luciano Amaro aponta para a existência de quatro espécies tributárias, senda elas: impostos, taxas, contribuições e empréstimos compulsórios. ${ }^{48}$ Há aqueles, inclusive, que não admitem atribuir-se às contribuições sociais regime jurídico tributário. ${ }^{49}$

Aqui, vemos que os autores optaram por utilizar critérios de classificação diversos, e não-somente o critério de vinculação imediata ou mediata da atuação estatal, muitas das vezes utilizando-se dois ou mais critérios simultaneamente. ${ }^{50}$ Assim, novas

J6 Para Paulo de Barros Carvalho "as contribuições são tributos que, como tais, podem assurnir feições de impostos ou taxas. Excluimos, de indústria, a possibilidade de aparecerem com os caracteres de contribuiçăo de melhoria, posto que esta espécie foi concebida em termos de estreito relacionamento com a valorização do imóvel, traço que não só prejudica com até impede seu aproveitamento como forma de exigência e cobrança das contribuiçōes". Idem, ibidem, p. 44.

47 Teoria da Imposição Tributária. 3. ed. São Paulo: LTr, 1998. p. 118.

48 Direito Tributário Brasileiro. São Paulo: Saraiva, 1997. p. 79 e ss.

49 Neste sentido: GRECO, Marco Aurélio. Contribuị̧ões (uma figura "sui generis"). São Paulo: Dialética, 2000. p. 69-116; CORREIA, Marcus Orione Gonçalves. Da natureza jurídica das contribuições previdenciárias. Revista das Faculdades Integradas Toledo, Araçatuba, v. 2, n. 1, p. 68-74, jun. 1999; CORREIA, Érica Paula Barcha. A natureza juridica das contribuiçōes sociais. Revista de Previdência Social. I.Tr, São Paulo, ano 22, n. 216, p. 943-952, nov. 1998. Contudo, vale notar que após a promulgação da Constituição Federal de 1988 a jurisprudência majoritária vem afirmando a natureza jurídica tributária das contribuições sociais.

50 "Algumas proposições teóricas, em confusas linhas, chegam a combinar os critérios de vinculação com finalidade. para alcançar uma qualificaçào das contribuições. Remédio de desespero. Ora, tal modalidade de proposta é, no minimo, estarrecedora, pelo equívoco metodológico que se alberga. Scria possivel agregarmos à classificação proposta por (ieraldo Ataliba, Paulo de Barros ou Sacha Calmon, de tributos vinculados ou não vinculados, construída tomando como critério i) a materialidade dos tributos, tal inovador critério ii): o da finalidade? A resposta é plenamente negativa. Nenhuma classificação pode aceitar dois critėrios classificatórios, a não ser que se eleja novo modelo classificatório; tampouco se poderiam combinar classificaçōes para, ao final, extrair-se como resultado conceitos de espécies do gênero tributo" "TÔRRES, Heleno Taveira. Pressupostos Constitucionais das Contribuiçuess de Intervenção no Dominio Econômico. A CIDE Tecnologia. In: ROCHA. Valdir de Oliveira (Coord.). Grandes Questōes Atuais de Direito Tribulário. São Paulo: Dialética, 2003.p. 114. 
espécies surgem de acordo com o critério utilizado, na tentativa de individualizar o regime jurídico aplicável a cada uma das espécies.

De fato, as maiores celeumas accrca da classificação das espécies tributárias giram em torno das contribuições e dos empréstimos compulsórios. Contudo, para a individuação da taxa a doutrina usa sempre o critério diferenciador da atuação estatal imediata.

Tendo por escopo classificar as exações fiscais formadoras da receita pública, ${ }^{51}$ Aliomar Baleeiro estabeleceu uma repartição entre receitas extraordinárias e ordinárias, ${ }^{52}$ sendo que esta última se subdividia $\mathrm{em}$ receitas ordinárias de economia privada e receitas derivadas ou de economia pública. A primeira corresponderia às rendas provenientes dos bens e empresas comerciais ou industriais do Estado explorados à semelhança dos particulares, já o segundo grupo de receitas corresponderia aos tributos (subdivididos, segundo o autor, em impostos, taxas, contribuições de melhoria e contribuições parafiscais) e às penalidades pecuniárias.

De fato. a Constituição não destina textualmente o produto da arrecadação das taxas. definindo sua afetação. Deste modo, não há previsão textual de que o montante arrecadado como contraprestação de serviço público específico e divisível seja destinado àquelc órgão ou instituição que promoveu determinado serviço, como forma de suprir suas necessidades materiais e remunerá-los. Ademais, como já salientamos, as destinações financeiras ou orçamentárias das exações não são cômodas para classificá-las do ponto de vista tributário, deste modo optamos por descartar classificações calcadas em bases financistas.

Uma classificação útil deve ter como base critério firme, metodologicamente aceitável para o fim que a classificação se propõe. Neste sentido, tendo em vista que o nosso fim precípuo é identificar, de forma coerente, o regime jurídico pelo qual se dá o pagamento de serviço estatal específico e divisivel, erigimos como método classificatório a competência. ${ }^{53}$

$\therefore \quad$ "Receita pública é a entrada que, int:grando-se no patrimônio público sem quaisquer reservas, condições ou correspondências no passivo, vem acrescer o seu vulto, como elemento novo é positivo"

52 Neste aspecto, levando-se em conta o critério de regularidade ou relativa pcriodicidade, pois as primeiras (receitas extraordinárias) padecem de caráter mais ou menos esporádico, ou, pelo menos, inconstante, e. não raro, excepcional. Seriam receitas extraordinárias, sob tal ponto de vista. os impostos decretados em circunstâncias anormais, as doações e legados (com ou sem encargo), os proventos adquiridos por efeito de prescrição, as heranças jacentes, bens vacantes, indenizações ou reparaçōes de guerra, entre outros. de caráter temporário, irregular e contingente. In: BALEFIRO, Aliomar. Uma Introdução à Ciência das Finanças. 5. ed., Rio de Janeiro: Forense, 1968. p. 130-131.

\$3 De fato, conforme leciona Huleno Tôrres, "a atribuição de regimes juridicos às espécies tributárias dependem inexoravelmente do critério que se adote para a qualificação do conceito maior de tributo" $F$ ainda salienta: " (...) como a Constituição não cria tributos, mas apenas dispõe competìncias, o máximo que a doutrina poderá fazer será classificar tais competências. também. E aqui se apresenta o que chamamos de 
A finalidade de determinado tributo, como vimos, tem sido utilizada por parte da doutrina como critério classificatório. Não-obstante ser de conhecimento geral que os imposto têm sua finalidade específica, bem como as taxas e as contribuições sociais e de melhoria, deve-se tomar certo cuidado ao utilizar-se tal critério como válido, sob pena de incidir em erro metodológico.

Assim, exclui-se a possibilidade do destino da receita ser utilizado como critério de classificação válido, posto que destinação de tributo é elemento de afetação de receita, na forma c no modo indicados pela Constituição Federal (verbi gratia, o disposto nos arts. 157 a 159 e também no art. 167, inciso IV desta Norma). Deste modo, poderíamos crer que todo tributo tem certa índole finalística sob a ótica do destino da receita auferida por sua constituição. ${ }^{54}$

Entretanto, a finalidade vista como "motivo constitucional" para o exercício da competência legislativa é coisa diversa. ${ }^{5 S}$ Neste sentido, salienta Heleno Tôrres que tal classificação "fundada no equilibrio entre função da competência e a designação da espécie de tributo. E só no caso das contribuições, que podem ter materialidade de imposto ou taxa, id est, de tributo vinculado ou não vinculado, dá-se essa particularidade. de exigência de adequado equilibrio entre o 'motivo constitucional' e os elementos da norma tributária (materialidade, base de cálculo e contribuinte). Sendo a competência

motivo constitucional para a ação do legislador na criação das leis tributárias, segundo o elemento erigido pela Constituição como fundamentação do agir legislativo: i) empréstimo compulsório e ii) contribuiçóes para atender finalidades preestabelecidas, como criação de previdências, investimentos relevantes, intervenção no domínio econômico etc.; iii) laxas, em vista da utilização de serviço público prestados de modo efetivo ou postos à disposicão do interessado; iv) contribuiçâo de melhoria, a partir de prévia construção de obras públicas (com valorização), para recuperação (total ou parcial) do seu custo; e v) impostos, quanto alo exercicio de competências, visando a formação do orçamento geral" Pressupostos Constitucionais das Contribuições de Intervenção no Dominio Econômico. A CIDE Tecnologia. In: ROCHA. Valdir de Oliveira (Coord.). Grandes Questôes Atuais de Direito Tributário. São Paulo: Dialética, 2003. p. 113 e 121.

$\therefore$ "Efetivamente, o destino da receita poderá servir como instrumento de classificação das receitas, mas não como meio para dizer da tipologia dos tributos e dos efeitos e legitimidade destes. Nào se pode misturar critérios distintos: endógenos, pertinentes à norma; e exógenos, tipicos para qualificar a destinação ou devolução do tributo. Quem assim opera, erra duplamente. Dentro e fora da própria classificação que pretende propor". E mais adiante. também neste sentido: "todo tributo é finalistico, yuando visto sob a útica do destino da receita auferida com sua constituição" Idem, ibidem, p. 115. Ademais, também dispõc o art. 4. ${ }^{\text {a }}$ do CTN: "A natureza juridica especifica do tributo é determinada pelo fato gerador da respectiva obrigação. sendo irrelevantes para qualificá-la: I - a denominação e demais características formais adotadas pela lei; II - a destinação legal do produto da arrecadação"

33 Conforme voto do Ministro Moreira Alves: "Assim, é da essência do regime juridico específico da contribuição para a seguridade social a sua destinação constitucional. Não a destinação legal do produto de sua arrecadação, mas a destinação constitucional, vale diser, o vinculo estabelecido pela própria Constituição entre a Constituição e o sistema de seguridade social. como instrumento de seu financiamento direto pela sociedade, vale dizer. pelos contribuintes" RE 146.733. Acórdão do Pleno. julgado em 29.06.1992. RTJ, n. 143, p. 691 . 
um dos elementos de validade da norma, prévio à sua existência, não saímos do critério eleito, que é tipicamente normativo" "i6

Deste modo, as espécies tributárias mantidas seriam três: (i) impostos; (ii) taxas e; (iii) contribuições de melhoria. Os impostos seriam tributos não-vinculados, existindo sem que seja necessária qualquer correspondência a uma atividade estatal no critério material de sua hipótese de incidência. As taxas seriam imediatamente vinculadas, pois no critério material de sua hipótese de incidência haverá determinada atividade estatal (nas modalidades poder de polícia ou serviço público). As contribuições de melhoria seriam mediatamente vinculadas. pois além da atividade estatal deverá haver a valorização imobiliária. Já as contribuições sociais, as contribuições de intervenção no domínio econômico ou outras espécies que geralmente incluem-se no gênero "contribuições" serão ou taxas ou impostos, de acordo com a análise da Regra-Matriz do tributo, mas com determinado "motivo constitucional" respectivo. 57

Temos então que o legislador, ao elaborar novo tributo, atentando-se para o "motivo constitucional" que determina seu "agir legislativo" criará um ou um imposto, ou uma taxa ou uma contribuição de melhoria. E isto se dá em razão da competência discriminada constitucionalmente, aqui utilizada como critério classificatório.

\subsection{A Regra-Matriz de incidência da taxa}

Salienta ainda Heleno Tôrres que "faz-se mister que se verifique a presença dos elementos típicos da Regra-Matriz de incidencia que lhe ofertam identidade. Sendo o tributo espécie de obrigação, construida como norma de conduta, a qualificação juridica de suas espécies deve vir a partir de uma análise da Regra-Matriz de incidência possivel,

s6 ROCHA. Valdir de Oliveira (Coord.). Grandes Questòes Atuais de Direito Trihutario. São Paulo: Dialética. 2003. p. $116-117$.

57 Heleno Tôrres, em análise apurada, opta por afastar outros critérios adotados por parte da doutrina, como a parafiscalidade, a possibilidade de devoluçào posterior e outros critérios finalisticos. preferindo utilizar-se do "motivo constitucional" para analisar mais detidamente as contribuições, posto que tal critério cleriva diretamente da competência, jả que a Constifuição atrela a criação de determinados tributos, vale dizer. vincula o agir legislativo, a uma determinada finalidade especifica, o "motivo constitucional" $\dot{E}$ dizer, acerca da exação tributária estatal, esta pode "decorrer de alguma forma dc agir estatal especifico. prestação de serviço público, exercicio de poder de polícia ou construção de obra pública; pode advir de algum ato desvinculado de qualquer agir estatal, revelador de capacidade contributiva: como poderá decorrer de situaçōes fáticas vinculadas à própria finalidade demarcada: as contribuiçōes, quanto a fatos juridicos tributários vinculados ao setor submetido à intervenção do Estado na economia, ao setor social no qual a Ĺniào deva atuar ou mesmo à relação corporativa entre filiado e entidade. E foi assim que a Constituição repartiu-os, pela tomada de tais pressupostos, dividindo-os en impostos, taxas c contribuições. Ocorre que às contribuições, não tendo definido expressamente a maioria das hipóteses de incidência, preferiu qui a norma de competencia servisse a esta finalidade. exigindo atuação da Lnião nas respectivas áreas" Idem ibidem, p. 116-125. 
pertinente aos elementos de composição deste (hipótese de incidència e base de cálculo), após sua efetiva instituição. Nunca antes" $\$ 8$

Não podemos então nos olvidar em analisar, mais detidamente, esta questão. Primeiramente, devemos observar que. de acordo com os ensinamentos de Paulo de Barros ('arvalho, a Regra-Matriz de incidência apresenta uma hipótese tributária, que é, de fato, o antecedente normativo. Assim sendo, a hipótese contém a descrição de um fato geral e abstrato, passível de ocorrência no mundo físico-social. ${ }^{59}$

Assim, quando um fato geral e abstrato descrito na hipótese de determinada norma tributária encontra correspondente em outro fato ocorrido na realidade físicosocial, haverá um processo de subsunção, no qual o fato físico-social será descrito em linguagem competente. Tal operação faz surgir o fato jurídico tributário, que é o fato físico-social com correspondente na hipótese tributária descrito em linguagem competente.

O fato jurídico tributário apresenta-se como sendo a norma individual e concreta expedida pelo órgão competente, em oposição à norma geral e abstrata, que contém a hipótese tributária.

Ainda, a Regra-Matriz de incidência, além de seu antecedente (a hipótese tributária), apresenta um conseqüente (através da relação lógica se A então deve ser B). Deste modo, a hipótese tributária descreverá de forma geral e abstrata o fato passível do ocorrência no mundo real, enquanto seu conseqüente prescreverá a possível relação jurídica que advirá desta ocorrência. ${ }^{60} 61$

58 Idem ibidem, p. 121.

59 "Em substância, recorta o legislador eventos da vida real e lhes imputa força de, relatados em linguagem competente, suscitar os comportamentos que entende valiosos, garantido suu ato de vontade, mediante a pressão psicológica de sançōes, associadas, uma a uma, a cada descumprimento de dever estabelecido. Mas o súdito. resistindo ao temor de punição do Estado, pode ser alvo do aparato coativo. inerente ao Poder Público, momento em que desencadeia efetivamente o procedimento sancionatório. No corpo dessa temática. encontraremos os conceitos de coerção, sanção e coação, categorias imprescindiveis ao conhecimento da matéria jurídica". CARVALHO. Paulo de Barros. Curso de nireito Tribulário. 14. ed. São Paulo: Saraiva, 2002. p. 242.

60 Paulo de Barros Carvalho esboça o seguinte enunciado: "a hipótese tributária está para o fato juridico tributário assim como a consequêencia tributária está para a relação juridica tributária. Os antecedentes da proporção figuram no mesmo plano - o plano normativo geral e abstrato; por outro lado. os conseqüentes da proporção aritmética fato juridico e relação juridica tributária também se acham no mesmo plano o plano que fala do mundo material dos objetos físicos e dos seres humanos". Idem ibidem, p. 244.

61 Excluimos, de pronto, a possibilidade de ser formada qualquer relação jurídica tributária sum que haja a respectiva norma individual e concreta ou o processo de subsunçăo. Deste modo, optamos por adotar a doutrina ora exposta (por pensarmos ser mais cocrente) em detrimento de outras que têm como base para o surgimento da rílação juridica tributária a mera ocorrência do fato gerador. 
Tal descrição hipotética contida no antecedente normativo (hipótese tributária) contém três aspectos, a dizer: (i) material; (ii) temporal e; (iii) espacial. Cuidemos, de início, do critério material.

Nas palavras de Paulo de Barros Carvalho: "Nele, há referência a um comportamento de pessoas, fisicas ou juridicas, condicionado por circunstâncias de espaço e tempo (critério espaciul e temporal)" ${ }^{62}$ É um fato, abstraído do mundo real, desvinculado das coordenadas de espaço e tempo. ${ }^{63}$

Assim, temos que formam, necessariamente, o critério material, um verbo, designativo de uma ação, e seu complemento predicativo, que também deverá existir. Contudo, o verbo não poderá ser impessoal, ou sem sujeito, ou de sentido completo, deverá ser sumpre um verbo pessoal e de predicação incompleta, necessitando sempre da presença de um complemento. ${ }^{64}$

Analisemos mais detidamente o critério material da hipótese de incidência das taxas sobre serviço. Dispõe nossa Carta Magna no art. 145, inciso II e também o CTN, no art. 77. que a taxa se prestará a remunerar a utilização, efetiva ou potencial, de serviço público especifico e divisivel.

Do exposto, concluímos que o critério material desta espécie deve guardar, necessariamente, relação com uma atividade estatal direta (imediata), usufruída ou deixado à disposição do contribuinte. Ademais, tal atividade estatal não pode ser qualquer uma, mas um serviço público, especifico e divisível. ${ }^{65}$

Deste modo, o critério se apresentaria de dois modos distintos: (i) utilizar serviço público específico e divisivel e; (ii) ter à sua disposição para ulilização serviço público específico e divisível.

i2 CARVAlHO, Paulo de Barros. Curso de Direito Tributário. 14. ed. São Paulo: Saraiva. 2002. p. 250.

6: "Dessa abstração emerge o encontro de expressões genéricas designativas de comportamentos de pessoas, sejam aqueles que encerram um fazer, um dar ou simplesmente, um ser (estado). Teremos. por exemplo, "vender mercadorias", "industrializar produtos", "ser proprietário de bem imóvel", "auferir rendas", "pavimentar ruas", ttc. Esse núcleo, ao qual nos referimos, será formado, invariavelmente. por um verbo. seguido do seu complemento. Dai porque aludirmos a comportamento humano. tomada a expressão na plenitude de sua força significativa, equivale dizer. abrangendo não só as atividades refletidas (verbos que exprimem ação) como aquelas espontâneas (verbos de estado, ser, estar, permanecer etc.)" CARVALHO, Paulo de Barros. Teoria da Norma Tributaria. 3. ed., São Paulo: Max Limonad, 1998. p. I24-125.

$\leftrightarrow$ Esclarece o autor: "Regressando ao tópico da transcendente importância do verbo, para a definição do antecedente da norma-padrão do tributo, quadra advertir que não se pode utilizar os da classe dos impessoais (como haver), ou aqueles sem sujeito (como chover), porque comprometeriam a operatividade dos designios normativos, impossibilitando ou dificultando seu alcance. Isso concerne ao sujeito, que pratica a açào. e bem assim ao complemento do predicado verbal, que, impreterivelmente, há de existir. Descabe falar-se. portanto, de verbos de sentido completo. que se expliquem por si mesmos. F́. forçoso que se trate de verbo pessoal e de predicação incompleta. o que importa a obrigatória presença de um complemento" ("urso de Direito Tributário. 14. ed. São Paulo: Saraiva, 2002. p. 252.

6. Sobre serviço público, observar o próximo tópico. 
Aqui temos então, conforme a teoria exposta, duas possibilidades de núclcos vurbais, quais sejam "utilizar" ou "ter à sua disposição" Esta duplicidade de núcleos verbais se dá por força da norma constitucional, que estabeleceu a incidência da taxa mesmo quando o serviço público específico e divisível não é utilizado. Contudo, é mister que se anote que, apesar da incidencia da taxa existir sem que haja a prestação do serviço, tal prestação deve estar sempre à disposição do consumidor, caso contrário será inconstitucional a exigência do tributo.

É o que se depreende da análise dos dispositivos normativos citados, já que o serviço público poderá ser auferido pelos contribuintes ou de forma efetiva ou de forma potencial. Destas duas possíveis formas derivam, conseqüentemente, duas estruturas formadoras do critério material da hipótese de incidencia das taxas.

O complemento do predicado verbal será sempre "serviço públicu específico e divisivel", caso o serviço não possua qualyuer dos três atributos, vale dizer (i) público, (ii) específico e (iii) divisivel, incidência de taxa não haverá.

Já no critério espacial buscamos observar o local em que se realizaria determinado fato, verificando se o critério espacial de determinada hipótese faz menção a determinado local para a ocorrência do fato típico, ou se alude a áreas específicas, ou se é bem genérico, abrangendo qualquer dos pontos geográficos em que vigore a lei instituidora. ${ }^{60}$

Com relação à taxa de serviço público. é de rigor observar que a norma instituidora do tributo será federal. estadual, distrital ou municipal, conforme consigna o art. 145, ao instituir a competência dos entes políticos para exigirem taxa. Assim, o âmbito do critério espacial da hipótese de determinada norma instituidora de taxa será igual à competência do ente federativo que criou a norma.

Neste sentido, sc determinado município institui determinada taxa em decorrência da utilização do serviço público da coleta de lixo. a amplitude espacial de vigência desta norma instituidora será igual ao limite do município respectivo. Pelo mesmo raciocinio, a amplitude espacial da norma poderá variar de acordo com a

66 Sobre o tema, salienta o autor: "Acreditamos que os elementos indicadures da condição de espaço, nos supostos das normas tributárias. hão de guardar uma dessas três formas compositivas, diretriz que nos conduz a classificar o gênero tributo na conformidade do grau de elaboração do critério espacial da respectiva hipótese tributária: a) hipótese cujo critério espacial faz mençào a determinado local para a ocorrência do fato lípico; b) hipótese em que o critério espacial alude a áreas especificas, de tal sorte que o acontecimento apenas ocorrerá se dentro delas estiver geograficamente contido: c) hipótese de critério espacial bem genérico. onde todo e qualquer fato, que suceda sob o manto da vigéncia territorial da lei instituidora, estará apto a desencadear seus efeitos peculiares" CARVALHO, Paulo de Barros. Teoria da norma tributária. 3. ed. Sào Paulo: Max Limonad. 1998, p. I31-132. 
amplitude geográfica do ente político competente que instituiu a norma, sendo federal, estadual, distrital ou municipal.

O critério temporal da hipótese tributária representa o âmbito temporal, o momento em que, no mundo dos fatos, se dará o fato $\mathrm{cm}$ abstrato descrito na hipótese. Ademais, a relevância deste critério está em que ele aponta o preciso instante em que se instalará o liame obrigacional em os sujeitos da relação jurídica tributária."

Tal marco temporal demonstra-nos o exato momento em que a prestação passa a ser exigida pelo sujeito ativo da relação. ${ }^{68}$ Nas taxas, o dever do pagamento da contraprestação pelo usuário de serviço público específico e divisível ocorre no exato momento em que há a utilização e mensuração adequada deste serviço. Deste modo, não basta mera utilização do serviço para dar ensejo à cobrança. é de mister que haja a mensuração devida, e só após isto o critério temporal se mostrará completo. ensejando a incidência da norma.

Nos casos cm que o serviço é deixado à disposição do contribuinte, o marco tımporal se dá também quando da mensuração, momento no qual se apurará a efetiva nãoutilização do serviço público. De fato, como afirma o dispositivo constitucional. haverá incidência de taxa mesmo quando não-utilizado o serviço público, contudo a contraprestação, neste caso, será diferenciada, conforme analisaremos posteriormente.

\subsection{O conseqüente da norma: breves asscrtivas aplicáveis às taxas}

('omo já salientamos, na ocorrência no mundo fático da situação abstratamente prevista na hipótese da norma (no critério material, temporal e espacial) haverá um processo de subsunção. O resultado de tal processo será o estabelecimento de uma relação jurídica, regulada pelo conseqüente da norma, ou prescritor. ${ }^{69}$

Tal conseqüente normativo, na análise de Paulo de Barros Carvalho, apresenta, assim como no antecedente, critérios que identificarão e facilitarão a análise da

67 "Comprecendemos o criterio temporal da hipótese tributária como o grupo de indicações. contidas no suposto da regra, e que nos oferecem elementos para saber, com exatidão, em que preciso instante acontece o fato descrito, passando a existir o liame jurídico que amana devedor e credor, em função de um objeto - 0 pagamento de certa prestação pecuniária" CARVALHO, Paulo de Barros. Curso de Direito Tributário. 14. ed. São Paulo: Saraiva. 2002. p. 255.

68 "O marco de tempo deve assinalar o surgimento de um direito subjetivo para o Estado (no sentido amplo) e de um dever juridico para o sujeito passivo". Idem ibidem, p. 258.

69 "Se a hipótese, funcionando como descritor, anuncia os critério conceptuais para o reconhecimento de um fato, o conseqüente, como prescritor, nos dá, tambèm, critérios para a identificação do vinculo juridico que nasce, facultando-nos saber quem é o sujeito portador do direito subjetivo; a quem foi cometido o dever juridico de cumprir determinada prestação; e scu objeto, vale dizer, o comportamento que a ordem jurídica espera do sujeito passivo e que satisfaz, a um só tempo, o dever que the fora atribuído e o direito subjetivo de que ira titular o sujeito pretensor". Idem ibidem, p. 278. 
norma concreta. Elenca tal autor os seguintes critérios: (i) critério pessoal; e (ii) critério quantitativo. $^{70}$

O critério pessoal identificaria mais precisamente os sujeitos desta relação juridica. Neste tipo de relação obrigacional (já que a relação jurídica tributária traz também em seu bojo uma obrigação), como em outras de indole privatística, haverá dois pólos: um sujeito ativo e um sujeito passivo.

O sujeito passivo "é a pessoa, fisica ou juridica, privada ou pública, de quem será exigido o cumprimento de prestação pecuniária, caracterizada como de natureza fiscul' "1 No caso da taxa, e sujeito ativo aquele que utilizou ou teve à sua disposição para utilização determinado serviço público específico e divisível, o qual estará, após o devido processo de subsunção, obrigado a recolher determinada quantia.

U sujeito ativo da relação juridica tributária é, por via de regra. o Estado, aqui visto no seu sentido lato. ${ }^{72}$ A possibilidade ou não de delegação da capacidade tributária ativa traz grandes conseqüências para a disciplina das taxas, principalmente as relacionadas à prestação de determinados serviços públicos por entidades particulares, através de contratos de concessão ou permissão. ${ }^{73}$

Além do critério pessoal temos o critério quantitativo, que se dissocia em: (i) base de cálculo e; (ii) alíquota. De fato, tais critérios têm como função precípua

70 "São componentes de uma relação juridica: a) um sujeito ativo. titular de um direito subjetivo; h) um sujeito passivo, de quem se espera o cumprimento de um dever juridico; e c) o conteúdo do dever juridico yue é o mesmo do direito subjctivo. Se pudermos saber quem são os sujeitos e qual o comportamento qui satisfaz o dever juridico. teremos condições de identifica determinado liame que se formou por lorça do acontecimento de um fato. Compreendidos na categoria ampla das relações jurídicas, mais precisamente naquelas de natureza obrigacional, os vinculos juridicos tributários haverão de ser examinados mediante a análise de dois critérios apenas: a) o critério pessoal, que servirá para reconhecer os sujeitos (ativo e passivo) da relação; e b) o critério quantitativo, que nos possibilitará determinar o conteúdo do dever jurídico a ser cumprido pelo sujeito passivo" CARVALHO, Paulo de Bartos. Teoria da Vorma Tributária. 3. ed. São Paulo: Max Limonad, 1998. p.161.

7 CARValHu, Paulo de Barros. Teoria da Norma Tribuária. 3. ed. São Paulo: Max Limonad, 1998. p. 165. É sabido que a obrigação tributária também tem suas peculiaridades acerca da sujeição, tema espinhoso para a doutrina, com a criação de categoria de sujeitos passivos, como aquele que tem vinculo econômico direto com o fato jurídico tributário, aquele sujeito por transferência (ocorrida ora por solidariedade, ora por sucessão, ora por responsabilidade), e aquele sujeito por substituição. Afastamo-nos desta análise, por acreditar ser impertinente para o correto deslinde do tema aqui posto. Para maiores informações sobri o tema consultar: SOUZA, Rubens Gomes de. Compêndio de Legislação Tribuiária. 2. ed., São Paulo: Edições Financeiras, 1954, p. 55 e ss.; e também TÔRRES, Heleno Taveira. Substituição tributária: regime constitucional, classificação e relações jurídicas (materiais e processuais). Revisıa Dialética de Dircito Tributário. Sào Paulo, n. 70. p. 87-108. jul. 2001.

"Nada impede, porém, que o legislador, titular da competència impositiva, atribua a outra pessoa, pública ou privada, a capacidade tributária ativa, importa dizer, a aptidão para integrar relação juridica de natureza fiscal, na condiçào de sujeito ativo ou, em outras palavras, a idoniedade para ser titular do direito subjetivo público. consistente em exigir deterrainada prestação pecuniária" ( ARV ALHO. Paulo de Barros. Teoria da Aorma Tribuciria. 3. ed. São Paulo: Max Limonad, 1998. p. 163.

Ohscrvar o próximo tópico. 
definição do quantum. o verdadeiro valor da prestação a sur cumprida pelo sujeito passivo. $^{74} \mathrm{O}$ critério quantitativo é definido de uma das duas formas seguinte: (i) estabelece-se uma importância determinada, precisando, desde logo, o conteúdo do dever jurídico a ser cumprido; ou, (ii) preocupa-se em dimensionar a materialidade do fato jurídico tributário, estipulando uma grandeza que the seja insita que, conjugada a outro fator numérico, possa determinar o quantum devido. ${ }^{75}$

Assim, muitas vezes a taxa tem um custo pré-fixado, igual para todos os contribuintes. Contudo, as situações devem ser analisadas especificamente, sob pena de inconstitucionalidade ou ilegalidade. $\mathrm{Na}$ verdade. tais situações só deveriam ocorrer quando a quantidade de serviço prestado é igual para todos os usuários, devendo, deste modo serem idênticas as contraprestações.

Desta forma, os valores cobrados a título de taxas variam de acordo com a quantidade do serviço prestado. Tal variação se deve à aplicação de uma grandeza, a base de cálculo. ${ }^{76}$

Com já vimos, o critério material da hipótese tributária apresenta um núcleo verbal e um complemento, e este complemento é que nos dará a dimensão da basc de cálculo. Devemos nos lembrar que concluímos serem duas as possíveis estruturações verbais do critério material da hipótese tributária das taxas (a saber, "utilizar" ou "ter à sua disposição") e que o complemento verbal será sempre serviço público específico e divisivel.

$74 \quad$ “(...) a esses elementos que o legislador faz inserir na consequiencia das endonormas tributárias c que, $\mathrm{cm}$ seu conjunto, nos permite precisar o conteúdo da prestação que haverá de sur cumprida pelo sujeito passivo, damos o nome de critério q̨uantitativo". Idem, ibıdem, p. 170.

75 Dois caminhos se abren ao legislador, quando se propõe editar endonorma tributária: a) ou estabelece importância determinada, precisando. desde logo, o conteúdo do dever jurídico a ser cumprido pelo sujeito passivo (caso dos tributos fixos, por exemplo: taxa em que o valor cobrado é igual para todos - CR\$ 30,00: ou impostos sobre serviços de prolissional liberal - dois salários mínimos); b) ou se preocupa em dimensionar a materialidade do fato jurídico tributário, estipulando uma grandeza que lhe seja ínsita c que, conjugada a outro fato numérico, possa determinar o "quantum" devido. A opção é incontornável; ou cstatui arbitrariamente a quantia que deve ser cobrada pelo titular do direito subjetivo ou busca a mensuração do próprio fato, mediante grandezas que institui. São essas as técnicas genéricas de estabelecimento do conteúdo do dever juridico, nos liames obrigacionais de índole tributária. Idem. ibidem, p. 170.

36 "Com efeito, sempre que o legislador pretenda medir a intensidade daquele "comportamento", limitado no tempo e no espaço, - constitui uma grandeza que se reveste de enorme significação para o Direito Tributário, posta também sua função adiáfora de confirmar o verdadeiro critério material da hipótese endonormativa - a base de cálculo" Idem ibidem, p. 171. Ademais. a basé de cálculo fornecé-nos importante fundamento teórico para a análise da estnutura do antecedente normativo. mais especificamente. do seu critério material. A base de cálculo deve expressar. inexoravelmente, a grandeza relativa ao critério específico que a endonorma resolveu englobar, atuando através do complemento do núcleo verbal. Pelas palavras do autor: "É lamentável que nem sempre exista base de cálculo, o que nos impede de contar com elemento segura para negar, confinmar e afimar o critério material das hipóteses tributárias" Idem, ibidem, p. 177. Para maiores informações confrontar: CANTO, Giberto de Ulhoa. Temas de Direito Tributário. Rio de Janeirn: Editora Alba. 1964. 
O complemento da base de cálculo tem três adjetivos para a expressão serviço: (i) público, (ii) específico e, (iii) divisível. Destes três adjctivos dois são requisitos de constitucionalidade para a cobrança de taxa, a saber, o caráter público e específico do serviço.

Temos então que o serviço deve ser público, como pressuposto para a cobrança deste tributo e mais, deve ser específico. Quis o constituinte afastar a ocorrência de situações abusivas costumeiramente aplicadas (como já expusemos no breve histórico), afirmando que não haverá cobrança de taxa sobre serviço caso este não seja especificamente dirigido ao contribuinte.

Já o adjetivo divisível, além de ser um pressuposto para a cobrança do tributo, atua como mensurador da quantidade de serviço recebido, influindo diretamente na base de cálculo do tributo. Deste modo, vemos que a divisibilidade do serviço mostrará a exata quantidade destinada à determinado contribuinte (já que o serviço deve ser sempre específico), e dará bases corretas para a diferenciação do quantum devido, definindo a profundidade da atuação estatal no caso concreto.?

Outro elemento que auxilia na composição do quantum devido é a alíquota, que atuará em cooperação com a base de cálculo neste sentido. É um importante componente, que pode ser representado sob a forma de percentual, como sói ocorrer, mas também pode ser representado em termos fracionários ou até mesmo em dinheiro. A análise da alíquota e suas aplicações nas taxas trarão importante embasamento teórico para o estudo do tema, remetemos tal análise em tópico posterior.

\subsection{O Princípio da Isonomia nas taxas e a capacidade contributiva}

O princípio da igualdade, corolário máximo dos regimes democráticos. vincula não só o aplicador da norma, mas, principalmente. o próprio legislador. que ao editar a lei deve se atentar à isonomia. ${ }^{78}$ Desde Aristóteles o verbete exegético deste

"Por derradeiro, resta mencionar que a base de cálculo está presente também nas conseqüências de endonormas que configuram taxas ou contribuição de melhoria (tributos vinculados a uma atuação estatal), na proporção em que, na maioria dos casos, mede a intensidade da atuação do Estado (taxa) ou a valorização imobiliària que ocorre por razão de atividade estatal (contribuição de melhoria).CARVALHO. Paulo de Barros. Teoria da Norma Tributária 3. ed. São Paulo: Max Limonad, 1998. p. 175.

"Assim, nào poderá subsistir qualquer dúvida quanto ao destinatário da cláusula constitucional da igualdade perante a lei, O seu destinatário é. precisamente. o legislador e, em conseqüência, a legislação: por mais discricionários que possam ser os critérios da politica legislativa, encontra no principio da igualdade a primeira e mais fundamental de suas limitaçòes" CAMPOS, Francisco. Direito Constitucional. São Paulo: Fd. Ireitas Bastos, 1956, v. II. p. 30. Seguindo o mesmo entendimento: "A Lci não deve ser fonte de privilégios ou perseguiçōes, mas instrumento regulador da vida social que necessita tratar eqüitativamente todos os cidadãos. Este é o conteúde politico-idcológico absorvido pelo principio da isonomia e juridicizado pelos textos constitucionais em geral. ou de todo modo assimilado pelos sistemas normativos vigentes. (...). 
princípio se manteve quase incólume: tratar igualmente os iguais e desigualmente os desiguais, na medida de sua desigualdadc. Do modo proposto, a isonomia não seria meramente formal, mas variável de acordo com o caso concreto, em razão do fator de discrimen ${ }^{79}$ colocado frente ao aplicador ou ao legislador.

Assim, pessoas diferentes em situações iguais ou pessoas iguais em situações diferentes podem ser amparadas pela lei de forma diversa, caso o fator discriminante (discrímen) seja justificável perante o princípio da igualdade.

A celeuma da isonomia estende-se também. como havia de ser, para os ramos fiscais e tributários. Aqui se busca um tratamento equânime entre os contribuintes. tendo em vista que todos devem contribuir economicamente de alguma forma para a manutenção do Estado. ${ }^{80}$

Sob esta ótica, o conteúdo deste principio adquire novo prisma no enfoque tributário do século XIX. Aqui se apregoava, pela tese intervencionista, que o Estado utilizasse seu poder de tributar para promover de forma mais ampla e eficaz a redistribuição de riqueza por meio da tributação progressiva e extrafiscal, como forma possível de se conter a insatisfação da distribuição de renda promovida pelo liberalismo econômico. $^{81}$

A justiça social manifestar-se-ia mediante dois aspectos da justiça fiscal: (i) a extraliscalidade e: (ii) progressividade. Nayuela busca-se a utilização do tributo como forma de controle da atividade econômica privada, onerando-se atividades socialmente insipientes, inócuas ou desinteressantes e favorecendo atividades de maior prestígio. que buscam o desenvolvimento social e econômico. Já esta teria por escopo garantir a

Em suma: dúvida não padece que. ao se cumprir uma lei, todos os abrangidos por ela há de receber tratamento parificado, sendo certo, ainda. que ao próprio ditame legal é interdito deferir disciplinas diversas para situações equivalentes" MELLO, Celso Antônio Bandeira de. O Conterido Juridico do Principio da Igualdade. 3. ed. São Paulo: Malheiros, 1999. p. 10.

79 De acordo com Celso Antônio Bandeira de Mello fator de discrimen válido seria o "critério legitimamente manipulável - sem agravos à isonomia - que autoriza distinguir pessoas e situações em grupos apartados para fins de tratamentos jurídicos diversos", assim, deve-se ponderar quais são as discriminações juridicamente intoleráveis. MELLO, Celso Antônio Bandeira de. Ibidem, p. 11.

"A igualdade na tributação tem a virtude de expor de maneira clara a relação juridica entre o cidadão e o Estado no àmbito obrigacional. Como primeira tese desenvolvida na justiça tributária alemã. a igualdade na tributação não adnute tratar os iguais de forma desigual e, da mesma sorte, não tratar os desiguais de forma igual. Essa teoria tomistico-aristotélica desenvolve a idéia de vetar um mecanismo igualitário que não leve em conta as desigualdades naturais" SPITALER, Armin. Der Gleichheilssalz (Ar. 3. Abs. I GG) in der Rechtsprechung der Steuergerichte. Colônia 1961, p. 11. Apud: ZILVETI, Fernando Aurilio. Principios de Dirciro Tributário e a Capacidade Contributiva. São Paulo: Quartier Latin. 2004. p. 120-121. 
isonomia, tributando-se progressivamente os cuntribuintes de acordo com sua capacidade contributiva, ${ }^{8 ?}$ providenciando uma coerente distribuição de renda. ${ }^{83}$

O constituinte brasileiro de 1988 grafou tal forma de tributar implicitamente no capul do art. $5^{\circ} \mathrm{e}$ de forma mais explícita no art. $145, \$ 1^{\circ}{ }^{84}$ A capacidade contributiva seria o princípio fundamental para a justiça fiscal, reunindo os direitos humanos

"A capacidade contributiva é o principio segundo o qual cada cidadão dive contribuir para as despesas públicas na exata proporção de sua capacidade econômica. Isso significa que as despesas públicas devem ser rateadas proporcionalmente entre os cidadãos, uma vez que estes tenham, poltencial ou efetivamente, usufruido a riqueza garantida pelo Estado. (...) Serve esse principio de instrumento para realizar a igualdade na tributação, atribuindo tratamento desigual aos desiguais. segundo a capacidade individual para arcar com o ònus tributário, dai ser o principio da capacidade contributiva considerado un corolário do principio da igualdade". ZILVETI, Fernando Aurélio. Principios de Direito Tributario e a Capacidade Contrihutiva. São Paulo: Quarticr Latin. 2004. p. 134. Também neste sentido, Francesco Moschelti conclui que a capacidade contributiva corresponderia a uma divisão eqüitativa das despesas na medida da capacidade individual de suportar o encargo fical. La Capacıà Contributivu. In: AMATUCCI, Andréa (Coord.). Tratrato di Diritto Tributário. Milão: Cedam, 1994. p. 244-248. Em sentido oposto observar: MACH. 1DO. Hugo de Brito. Os Principios Jurídicos da Tributação na ('onstituição de 1988. São Paulo: Dialética. 2001. p. 74.

*i "A justiça social propõe o uso da tributação com a finalidade de redistribuir a riqueza, buscando realizar a igualdade por meio de normas de cunho eminentemente sucial. Intretanto, as normas de finalidade financeira, como o art. 145. $\$ 1^{\circ}$ da Constituição Federal, propōem o bloqucio ou a contenção do poder de tributar, mantendo sua finalidade de justiça fiscal" FERRAZ JI'NIOR. Tércio Sampaio. Princípio da Igualdade no Sistema Tributário, conferência proferida um curso promovido pelo Instituto Inturnacional de Direito Público e Empresarial c Tribunal Regional Federal da $3^{\lrcorner}$Região. Revista de Direito Tributário. São Paulo, v. 15, n. 58. p. 200-226, out.-de\%. 1991. Tambum neste sentido, mas com um ponto de vista mais realista: "Pela igualdade material procura-se prover a todos, em igual medida, dos meios essenciais à vida. A igualdade material é, assim. identificada com a justiça social, uma causa nobre, porém comprovadamente pouco realizável". ZILVETI. Fenando Aurélio. Principios de Direito Tributário e a Capacidade Contributiva. São Paulo: Quartier Latin. 2004. p. 123.

"Tal principio encontra-se na nossa evolução constitucional. Na Carta Constitucional do Império, o art. 179. inciso $X \mathrm{~V}$, assinalava:

Art 179 A inviolabilidade dos Direito (ivis. e Politicos dos Cidadãos Brazileiros, qui tem por basi a liberdade, a scgurança individual. e' a propriedade. é garantida pela Constituição do Império. pela maneira seguinte:

$X V$. Ninguém será ixemplo de contribuir para as despesas do Estado em proporção de seus haveres

$\mathrm{Na}$ Constituição de 1946, previa o art. $2^{\circ}$

Art. 202. Os tributos terão cartiter pessoal sempre que isso for possivel e serĩo graduados conforme a capacidade economica do contribuinte.

A Carta de 1967/1969, de forma mais implicita:

Arr. 150. A Constituiçâo assegura aos brasileiros e aos estrangeiros residentes no Pais a inviolabilidade de direilos concernentes à vida, à liberdade è à propricedade, nos termos seguintes:

\$ 35. A especificação dos direitos e garantias expressos nesta Constituição não exclui outros direitos decorrentes do regime $e$ dos principios que ela adota.

Na Constituição atual:

1rt. 145. A União, os Estados, o Distrilo Federal e os Municipios poderào instituir os seguintes Iributos:

$\S 1^{\circ}$. Sempre que possivel. os impostos terão caráter pessoal e serão graduados segundo a cupacidade económica do contribuinte. facultados à administraşào tributária, especialmente para conferir esses objetivos, identificar, respeitados os direitos individuais e nos termos da lei. o patrimônio. os rendimentos e as atividades econômicas do contrihuinte. 
fundamentais na limitação do poder de tributar, compondo um quadro valorativo de tensão e ponderação na aplicação das garantias constitucionais. ${ }^{85}$

() que se propôe através da capacidade contributiva é o dever de concorrer cada qual na proporção de suas possibilidades para o custeio do Fstado (ability to pay principle). Contudo, há limites constitucionais que orientam a aplicação desta forma de tributar, como o direito de propriedade, o de não-confisco, entre outros, que buscam afastar a ganância fiscal e resguardar a correta aplicação do princípio da igualdade ${ }^{86}$

Sobre a Capacidade Contributiva nas Taxas, há muito vem se discutindo a aplicação deste princípio nas taxas, tendo $\mathrm{cm}$ vista que esta espécie tributária não tem a capacidade de, em sua Regra-Matriz de incidência, mensurar com exatidão a capacidade contributiva do contribuinte. ${ }^{\mathrm{X} \text { ? }}$

De fato, a base de cálculo das taxas não pode ser utilizada com o intuito de apontar uma riqueza (atributo) do contribuinte. Ademais, usufruir serviço público é algo

85 TORRES, Ricardo Lobo. A Lugitimação da Capacidade Contributiva e dos Direitos Fundamentais do Contribuinte. In: SCHOUFIRI, Luis Eduardo (Coord.). Direito Tributário em Homenagem a Alcides Jorge Costa. São Paulo: Quartier Latin, 2002. p. 434. De fato, a definição de capacidade contributiva e sua efetiva relevância juridica é assunto reiteradamente discutido na doutrina. Aqui, apenas para fixarmos algumas premissas, sem adentrar em pormenores, salientamos quc capacidade contributiva não corresponde necessariamente com poder econômico ou disponibilidadc monetária atual. Nesse sentido: "Sendo o tributo uma exigência feita à riqueza privada operada pelos poderés públicos. não se acrescenta muito quando, interpretando a norma constitucional sobre "capacidade contributiva", se conjuga esta capacidade em termos de 'poder econômico" com que fazer frente à exigência fiscal, de 'consistência econômica' do contribuinte, de "disponibilidades monetárias atuais'" DE MITA. Enrico. O Principio da Capacidade Contributiva. In: FERRAZ, Roberto. Principios e Limites da Tributação. Säo Paulo. Quartier Latin, 2005. p. 226. Observar, também em sentido próximo: MAFFEZZONI, Federico. Il Principio di Capacilà Contributiva nel Diritto Finanziario. Torino: UTET, 1970, especialmente p. 285 e ss; MOLINA, Pedro Manuel Herrera. Capacidad Económica y Sistema Fiscal: análisis Del ordenamiento español a la luz de Derecho alemán. Madrid e Barcelona: Fundación Oriol-Urquijo e Marcials Pons, 1998, p. 127 e ss (especialmente sua análise sobre progressividade na jurisprudência da Corte Constitucional Espanhola).

86 "Assim, devemos atentar para o fato de se considerar que, se a igualdade é justa nas vantaguns sociais, também deve ser nos ônus ou nas contribuições públicas". SÃO VIC'ENTE, José Antônio Pimenta Bueno, Marquis de. Direito Público Brasileiro e Análise da Constituiçào do Império. Rio de Janeiro: Edição do Ministério da Justiça e Negócios Interiores - Serviço de Documentação, 1958. p. 411.

"Há oitenta anos, ao tratar da capacidade contributiva, interpretando o art. 134 da Constituição de Weimar, Anschülz entendeu que o constituinte quis, com a expressão im verhälınis ihrer Mittel (em proporção aos seus meios), propor que a tributaçào respeitasse u principio da capacidade contributiva, relacionada especificamente com os impostos diretos, em especial com os de caráter pessoal, aplicável também às taxas e contribuições, porém, sem aplicaçăo para os impostos indiretos" (...). "As taxas e as contribuições de melhoria podem encontrar justificativas no principio da capacidade contributiva. Souza afirma que a contribuição de melhoria "aproxima-se dos impostos porque incide sobre valorização, que é índice de capacidade contributiva.' O Estado deve respeitar o princípio, na execução de suas políticas extrafiscais de prestação de serviços ao cidadão ou na implementação de beneficios especificos, como a pavimentação de nıas e instalação de infra-estrutura básica para a população" ZILVETI, Fernando Aurélio. Principios de Direito Tributário '’ a Capacidade Contributiva. São Paulo: Quartier Latin, 2004. p. 123. Para tais afirmações o citadu autor baseia-se respectivamente em: ANSCHÜTZ, Gehard. Die Verfassung dês Deutsihen Reichs. Hermann Gentner. Bad Homburg Von dher Höhe, 1960. p. 616; SOUZA. Rubens Gomes de. Compêndio de Legislação Tributária. Sảo Paulo: Resenha Tributária. 1975. p.438. 
no mais das vezes necessário, não sendo base segura para que se imponham quaisquer diferenciações entre contribuintes.

Neste sentido Eduardo Botallo leciona que "são as taxas, porque informadas pelo princípio da redistribuição, inteiramente distanciudas do principio da capacidade contributiva" 88 Também corrobora para este fim Ruy Barbosa Nogueira, ao esclarecer que as taxas têm como base a vantagem especial de qu心 usufrui o individuo, enquanto os impostos têm a capacidade contributiva como sua base, de modo que não é possível por meio da cobrança de taxas apurar qualquer capacidade contributiva do cidadão. $^{89}$

Contudo, há aqueles que lecionam em sentido oposto. Miguel Angel Caamaño Anido salienta que o princípio da capacidade contributiva se mantém presente nas taxas." Com entendimentos semelhante, Ricardo Lobo Torres entende que o legislador, ao fixar o valor das taxas deve pautar-se pela coerência, de modo que nãoonere excessivamente aqueles que não tenham condições de suportar a carga, porém precisam fazer uso do serviço. ${ }^{91}$

Também segue este entendimento Alcides Jorge ('osta, esclarecendo que " $a$ taxa. como tributo que é, pode e deve adequar-se à capucidade contributiva do contribuinte e pode ser utilizada como instrumento de politica tributária, para sobretudo em relação ao poder de policia - dificultar cerlas atividades ou, de modo geral, restringir o acesso a cerlos serviços públicos" "2?

A estrutura da endonorma das taxas aponta para uma solução. Não há correlação lógica entre a quantidade de serviço público auferido (base de cálculo) e a riqueza do contribuinte, frisando-se que, na maioria dos casos ocorre o uposto, já que a população mais carente é que se vale em maior quantidade dos serviços públicos colocados à sua disposição pelo Estado.

O que sc poderia sugestionar é a possível utilização de elementos externos à norma tributária que possam ser utilizados como forma de apuração da capacidade contributiva. Assim, aqueles que se encontrarem em situação de miserabilidade, apurada por critérios diversos, poderão ter acesso menos oneroso a tais serviços.

88 Capacidade Contributiva. Revisı de Direito Tributário, n. 47, p. 240.

89 NOGUEIRA, Ruy Barbosa. Principios e Conceitos Cientificos da Tributação, como Pressupostos para a Legislação e para a Interpretação e Aplicaçào do Dircito Tributário. Revvista Dialética de Direito Tributúiros, São Paulo, n. 36, set. 1998. p. 95-105.

90 ANIDO, Miguel Angel Caamaño. Concurrenia de Tasas y Capacidad ('ontributiva. Revista de Direito Tribulário, São Paulo. v. 15, n. 58, p. 90-98, p. 96, out./dez. 1991.

91 TORRES, Ricardo Lobo. Curso de Direito Financeiro. Rio de Janeiro: Renovar. 1999. p. 349.

92 MARTINS. Ives Gandra da Silva (Org.). Caderno de Pesquisas Triburarias, n. 10. Temas: Taxa e Preço Público. São Paulo: Rèsenha Tributária, 1985. p. 6. 
Tal solução não é a mais agradável. A utilização de elementos externos interferindo diretamente na dinâmica normativa pode ser prejudicial, criando situações discrepantes. ${ }^{93}$ Acreditamos que a taxa (especialmente aquela cobrada em virtude de serviço público) não é a forma exacional mais coerente e oportuna para ser utilizada como instrumento de justiça social no intuito de redistribuição de renda.

Para perseguir este fim de justiça social e redistribuição de renda o Estado deve valer-se de meios exacionais coerentes. A taxa não é modalidade exacional hábil para tal fĩm, seu escopo é remunerar prestação de serviço público, com o intuito de conservar e ampliar tal prestação.

Ademais, a universalização do serviço público, escopo constitucional, conforme a interpretação do art. 175, justifica um tratamento físcal apropriado às taxas, de forma a ampliar e estimular, sempre, o acesso a determinado serviço, e não afastá-Jo. Não é este o entendimento dominante dos nossos tribunais, como aponta a jurisprudência do STF. $^{94}$

93 Acqui a problemática pode se estender. A própria base de cálculo, que integra o conscqüente normativo, nâo pode ser utilizada como discrimen válido para diferenciar cobranças (como sói ocorrer na maior parte dos tributos). Outros elementos normativos, por si só, como se apresentam na norma desta espécie (como o subjetivo) não são suficientes para que justificar o discrimen. Assim, qualquer fator de discrimen (aliquotas diferenciadas em função da quantidade de serviço auferida) seria inconstitucional, por férir o principio maior da isonomia.

Esclareceu o Ministro Celso de Mello. no acórdão citado: " $\wedge$ base de cálculo dessa lípica taxa de policia não se identifica com o patrimônio liquido das empresas. inocorrendo, em conseqüência. qualquer situação de ofensa à cláusula vedatória inscrita ro art. $145 . \S 2^{\circ}$. da Constituição da República. O critério adotado pelo legislador para a cobrança dessa taxa de policia busca realizar o principio constitucional da capacidade contributiva, também aplicável a essa modalidade de tributo, notadamente quando a taxa tem, como fato gerador, o exercicio do poder de policia" Ag. Reg. No Recurso Extraordinário. RE n. 216.259 - C.F, Relator Ministro Celso de Mello, Segunda Turma, julgado em 09 de junho de 2000. publicado no Diário da Justiça em 19 de junho de 2000.

Esclareceu o ministro Carlos Velloso: "Realmente, embora a norma especílica da Constituição Fedural de 1988. pertinente ao principio da capacidade contributiva, ou mais exatamente, da capacidade econòmica, na tributação, diga respeito apenas aos impostos ( $\mathrm{CF} / 88$, art. $\left.145, \S 1^{\circ}\right)$, nada impede scja tal principio observado com relação às taxas. Aliàs, isto se dá quando a lei isenta destas o economicamente carente, e jả ocorreu com a Taxa Rodoviária Única, sem que ninguém sequer o colocasse em dúvida. Ressalto. finalmente, que a Taxa de Fiscalização que se cuida, destina-se ao custeio da atividade desenvolvida pela Comissão de Valores Mobiliários. em proveito direto daqueles que participam do mercado de valores mobiliários. Sua cobrança, portanto, realiza o principio da justiça tributária. Pagam aqueles que se beneficiam diretamente da atividade cstatal respectiva. Seria injusto que a sociedade tivesse de remunerar. pela via dos impostos, a atividade da CVM, que pertine dirtamente a um segmento da sociedade, perfeitamente identificado, composto pelas pessoas que participam do mercado de valores mobiliários. Por sinal, um dos segmentos da sociedade brasileira dotado de maior capacidade contributiva, relativamente à maioria da populaçāo" Recurso Extraordinárı, RE n. 177.835 - PE. Relator ministro Carlos Velloso. Tribunal Pleno, julgado em 22 de abril de 1999, publicado no Diário da Justiça em 25 de junho de 2001.

De fato, aqui a questão trata de taxa em razão do exercicio de poder de policia, mas o raciocinio poderia ser aplicado também para as outras situações que ensejam a cobrança de taxa cm razão da utilização de serviço público. 
Conforme já firmamos, não pensamos ser esta a solução ideal. Mais coerente seria a cobrança igualitária, em razão da quantidade de serviço público auferido, nu a tributação, caso fosse esta a intenção, de imposto específico, objctivando a tributação da capacidade contributiva, com aliquotas diferenciadas para cada manifestação de riqueza.'

Já a extrafiscalidade, como já mencionamos, é uma forma do Estado incentivar ou não determinada conduta, através dos tributos. ${ }^{96}$ Portanto, ela pode servir à indução do cidadão à determinada prática, como quando o Estado isenta de impostos determinada região geográfica, determina alíquotas diferenciadas para tributos de setores econômicos desfavorecidos ou varentes de desenvolvimento tecnológico. Também pode atuar com o intuito de desestímulo, tributando de forma mais rigorosa, como ocorre com produtos como o cigarro e bebidas alcoólicas, visando desestimular o consumo.

Podemos verificar, na taxa federal de controle e fiscalização ambiental TCFA, ${ }^{9-}$ cobrada em relação ao exercício do poder de policia utilizado na fiscalização e controle das atividades potencialmente poluidoras e que utilizem recursos naturais. Através desta exação, pretende-se a imposição de uma taxa progressiva, progressividade esta que varia de acordo com o potencial econômico da empresa e de seu potencial poluidor. 98

Acerca das taxas remuneratórias de serviço público, esta técnica fiscal tem sido aplicada com freqüência. Assim, na taxa sobre a utilização de energia clétrica, aplicase preço diferenciado quando a quantidade de energia elétrica auferida ultrapassa

95 Interessante observarmos que i impossivel haver taxa e imposto com base de cálculo idênticas, conforme preleciona o art. 145 , parágrafo $2 .^{\circ}$. da Constituição Federal. Assim, o legislador deverá optar por taxa ou imposto, de acordo com as especificidades que o tato fisico-social apresenta.

96 "Por meio da extrafiscalidade, o Estado pratica a justiça social, não necessariamente a justiça fiscal. Pode desenvolver suas políticas setoriais para atingir as mais diversas atividades do cidadão, mesmo sem conteúdo econòmico. sempre que sua intervenção se faça necessária. (...) ocorre a direção ou induçào do particular, que se vê forçado a adotar condutas. Para este estudo importa a indução do contribuinte, por meio de incentivos e desincentivos fiscais"..ZILVETI. Fernando Aurélio. Principios de Direito Tributario e a Capacidade Contributiva. São Paulo: Quartier Latin, 2004. p. 190. Sobre o papel do Estado na regulação de atividades por intermédio dos tributos. Iributos indutores e participação do Estado intervencionista, obscrvar: SCHOUERI, Luis Eduardo. Contribuição ao Estudo do Regime Juridico das Normas Tributarias Indutoras como Instrumento sobr o Dominio Economico. Tese de Titularidade. São Paulo: Faculdade de Direito da USP, 2003. p. 57-60. Por oportuno, Aliomar Baleeiro fez interessante distinção entre os tributos puramente fiscais e os tributos que assumem funções extrafiscais ou regulatórias. BALEEIRO. Aliomar. Limitações Constitucionais ao Poder di Tributar. Rio de Janeiro: Forense. 1997. p. 201.

97 Introduzida no ordenamento pela Lei n. 10.165, de 27 de dezembro de 2000.

98 Um dos exemplos mais marcantes da aluação extrafiscal do Estado e a progressividade é o IPTU progressivo, matéria que gerou muitas discussões doutrinárias. Neste sentido observar: GRECO. Marco Aurélio. IPTU - Progressividade - Função Social da Propriedade. Revista de Direito Tributário. n. 52. p. 120; OLIVEIRA, Yone Dolacio. Progressividade do IPTU e Princípios da Capacidade Contributiva e da Redistribuição. Revista de Direito Tributário. n. 17.p. 45; MACHADO, Hugo de Brito. Progressividade no IPTU. Repertório IOB de Jurisprudencia, n. 16/90, p. 258 
determinada media em quilo watt $(\mathrm{kWh})$. É nítida a lunção extrafiscal. Pretende o legislador incentivar o consumo racional de energia elétrica, premiando a economia de energia elétrica com aliquotas menores e, do mesmo modo, pretende desestimular o consumo exacerbado, fazendo incidir alíquota maior sobre o excesso. Tal política evidencia-se tambím nas taxas sobre o consumo de água. ${ }^{99}$

É claro que tal política na tributação encontra limites, muitos deles constitucionais. Sob este aspecto, "o exagcro da extrafiscalidade, como se observa em determinadas exações, reprime o contribuinte ao ponto de expropriá-lo do hem objeto da tributação, como nos impostos sobre o patrimônio" ${ }^{100}$ Como limites apunta-se o respeito ao direito de propriedade, ao direito da liberdade e o princípio do não-confisco.

Deste modo, não pode o legislador, sob o intuito de induzir condutas mediante tributo, abusar da técnica extrafiscal nas taxas, pois como vimos, tal modalidadu exacional não serve, por si-só, como forma de mensurar capacidade contributiva, além de servir precisamente para remunerar scrviço público, que, no mais das vezes, é essencial à boa parte da população.

\section{Serviço Público, específico e divisível}

\subsection{Serviço Público}

Como já frisamos, um dos elementos da endonormas das taxas cobradas em razão da utilização de serviço público é o próprio serviço público, específico e divisível. Assim, passaremos a analisar a que tipo de serviço nossa legislação elegeu conceder o stutus de público.

As primeiras noções francesas mostram-nos uma visão ampla de serviço público, considerando-o como sendo qualquer atividade ou organização do Estado. Leon Duguit inclusive professou que o próprio Estado seria, de fato, uma cooperação de serviços públicos organizados e fiscalizados, noção que se aproxima de soberania. ${ }^{101}$

Acerca do aqui salientado, importante notar o que ocorreu em 2002, durante a crise de energia clćtrica. conhecida popularmente como "apagão" No intuito de desincentivar gastos excessivos, tal política extrafiscal foi posta em ação de forma mais premente.

ZILveti, Fernando Aurélio. Principios de Direito Tribulário e a Capacidade Contriburiva. São Paulo: Quartier Latin. 2004. p. 200.

101 DUGUlT. Lecon. Mantel de Droit Constitutionnel. Paris: Fontemoint et Cie.. 1911. Observar rambém. no mesmo sentido: BONNARD, Roger. Précis de Droit Adininistratif. Paris: Libraric du Recueil Sircy, 1953. Apud: DI PIETRO. Maria Sylvia Zanella. Dirrito Administratio. 14. ed. São Paulo: Fditora Allas, 2002. p. 95. 
Tal conceituação ampla tem uma visão finalista do serviço público, levando em consideração a finalidade pública nèles contida. ${ }^{102}$ Assim, abrangeria, além da atividade própria da administração pública, também os serviços jurisdicionais. 「́: neste sentido que Hely Lopes Meirelles conceitua o instituto: "lodo aquele prestado pela Administração ou por seus delegados, sob normas e controles estatais, para satisfazer necessidades essenciais ou secundárias da coletividade, ou simples conveniência do Estado" 103

Por outro lado, alguns administrativistas adotam um conceito mais restrito. Assim se encontra o conceito de Celso Antônio Bandeira de Mello, salientando a pessoalidade (prestado pelo Estado ou por quem lhe faça as vezes), o regime jurídico público e a prestação direta deste serviço. ${ }^{104}$ Maria Sylvia Zanella Di Pietro encontra solução semelhante, esclarecendo também que mesmo a prestação indireta do serviço poderia ser ele considerado como público. ${ }^{105}$

Interessante observar que ambos os doutrinadores abarcam, como sendo serviços públicos, aqueles prestados por entes diversos do Estado. Assim terceiros legalmente legitimados poderiam, por sua vez, prestar atividades específicas do Estado. Ademais, outro ponto de confluência é a idéia de finalidade pública, presente em ambos os conceitos.

Salienta Maria Sylvia que três critérios são utilizados para a definição de serviço públicos, a saber: (i) subjetivo; (ii) material e: (iii) formal. Assim. o subjetivo "considera a pessoa jurídica prestadora da atividade: o serviço público seriu aquele prestado pelo Estado" 106 O material "considera a atividade exercida: o serviço público

10? Neste sentido abrangente e finalista, serviço público seria "toda atividade que o Estado exerce para cumprir os seus fins". MASAGÃO, Mário. Conceito de Direito Administrativo. São Paulo: Escolas Prolissionais Salesianas, 1926. p. 252. Apud: Idem, Ibidem, p. 95.

103 MEIRELLES, Hely Lopes. Direito Administrativo Brasileiro. São Paulo: Malheiros, 1996. p. 296.

104 "(...) serviço público ¿̇ toda atividade de oferecimento de utilidade ou comodidade material fruivel diretamente pelos administrados, prestado pelo Estado ou por quem the faça as vezes, sob regime de direito público portanto consagrado de prerrogativas de supremacia e de restriçōes especiais - instituido pelo Estado em favor dos interesses que houver definido como próprios no sistema normativo". MELLO, Celso Antonio Bandeira de. Prestação de Serviços Públicos e Administração Indireta. São Paulo: Revista dos Tribunais, 1975. p. 96.

105 "Tal conceito restringe demais com a expressão utilidade un comodidade fruivel diretamente pelos udministrados. Neste suntido, scriam serviços públicos, por exemplo. o da água, o de transportes, o de telecomunicaçōes, o de energia elétrica. pois estes são fruiveis diretamente pelos administrados. Mas existem outras espécies de serviços que são considerados públicos e nem por isso süo usulruíveis diretamente pela coletividade. Assim é o caso dos serviços administrativos do Estado, prestados internamente, dos serviços diplomáticos, dos trabalhos de pisquisa cientifica, os quais só por via indireta beneficiam a coletividade" DI PIETRO, Maria Sylvia 7anella. Direiro Administrativo. 14. ed. São Paulo: Editora Atlas, 2002. p. 97. 
seria a atividade que tem por ubjeto a sutisfação de necessidades coletivas" 107 Por fim, o formal "considera o regime juridico: o serviço público seria aquele exercido soh regime de direito público derrogatório e exorbitante do direito comum" 108

Num primeiro momento utilizava-se, simultaneamente, as três noções. Deste modo "serviço público abrangia as atividades de inieresse geral, prestadas pelo Estado sob regime juridico publicístico" 109

Posteriormente, com a falência do modelo estatal apregoado pelo liberalismo, na transição para o estado de bem-estar social, o Estado inicia participação mais freqüente e influente na economia. Assim, não o aposte de capital estatal, mas sua participação em situações antes tipicamente privadas alterou a visão de serviço público. afetando seu núcleo formal.

No início dos anos 80, com a crise do estado de bem estar social e a adoção quase unânime de modelos neoliberais, o conceito de serviço público sofre outro ataque. ${ }^{110} \mathrm{O}$ Estado inicia movimentos reversos, delegando funções que antes exercia aos particulares, por meio de contratos de concessão de serviços públicos e, posteriormente, por meio das pessoas juridicas de direito privado criadas para este fím, como é o caso das empresas públicas e sociedades de economia mista, para execução sob regime jurídico predominantemente privado. Aqui, vemos que o núcleo formal e o subjetivo foram afetados.

Deste modo, o elemento subjetivo teve que sofrer modificações, pois não só as pessoas jurídicas de direito público são executoras de serviços públicos, já que os particulares podem atuar neste suntido por delegação. E bem assim o elemento formal, já que o regime jurídico de muitos serviços públicos não é exclusivamente publicístico.

Dai falar-se em "crise na noção de serviço público" Hodiernamente a cumulação dos três elementos é menos freqüente, como bem frisou Jean Rivero." Assim

107 DI PIE'TRO, Maria Sylvia Zanella. Direito Administrativo. 14. ed. Sào Paulo: Editora Atlas, 2002. p. 97.

108 Id. Ibid., p. 97.

109 Id. Ibid., p. 97.

110 "No inicio dos anos 80, uma grande parte do discurso sobre os problemas e desenvolvimento futuros do Estado de bem-estar focalizava o alegado antagonismo entre o aspecto de garantia civil coletiva do kistado (isto é, do Estado do bem-estar) e os aspectos liberais do Estado (isto é, suas garantias de propriedade privada, de relaçōes de mercado contratuais e, consequientemente, de uma cconomia capitalista). Esse discurso, em que prevalecem as perspectivas filosóficas e politicas da direita neoconservadora e liberal, postula que o Estado do bem-estar se tornou um peso muito grande para a economia, cujo crescimento potencial e a competitividade estariam, conseqüentemente, sofrendo os custos e a rigidez excessivos impostos sobre o mercado pelas condições organizadas pelo Estado do bem-estar e pela organização da previdência social" OFFE, Claus. Capitalismo Desorganizado. São Paulo: Brasiliense, 1995. p. 272.

I11 Tal autor, ao ponderar sobre a questâo, segundo análise de Maria Sylvia. alirma que: "Existem necessidades de interesse geral que a autoridade atende satisfatoriamente. mas que nem por isso confia a órgãos públicos; e também pode acontecer que entidades públicas, como autarquias, desempenhem atividade industrial ou comercial idêntica à das empresas privadas similares, e que não pode ser considerada serviço público, uma 
tem-se a nova definição de serviço público: "loda atividade material que a lei atribui ao Estado para que a exerça diretamente ou por mcio de seus delegados, com o objetivo de satisfazer concretamente às necessidudes coletivas, sob regime juridico tolul ou parcialmente público" 112 Os três elementos permanecem neste conceito, mas com sensivel diferenciação.

O elemento subjetivo, conforme preceitua o art. 175 da Constituição Federal, ${ }^{113}$ preconiza que o serviço público será sempre incumbência estatal. Outrossim, o mesmo dispositiva possibilita a delegação do mesmo, por lei. Deste modo, "a sua gestão também incumbe ao Estado, que pode fazê-lo diretamente (por meio dos próprios órgãos que compõem a Administração Pública centralizada da União, Estados e Municípios) ou indiretamente, por meio de concessão ou permissão. ou de pessoas juridicas criadas pelo Estado com esta finalidade" 114

O elemento material é a finalidade pública do serviço. Quando particulares exercım atividades deste feitio raramente este é o interesse principal, pois o quc os move, via de regra, é o interesse particular. Adımais, não é suficiente o objetivo de interesse público, é de mister que a lei atribua tal objetivo. Daí as afirmações de que o serviço público pode muito bem funcionar com prejuízo, já que a gratuidade è a regra nessa âmbito. 115

Assim. conforme expusemos nestas breves linhas. tomaremos esta por ser a noção de serviço público para o fim a que se propõe este trabalho.

vez que nenhuma peculiaridade distingue o seu regime adotado no setor privado. Há, aí, uma dissociação dos sentidos subjetivo é material. A dissociação é igualmente freqüente entre os dois primeiros sentidos e o regime juridico de serviço público: os serviços comerciais e industriais do Estado são exercidos pelas empresas estatais sob regime jurídico de direito privado, parcialmente derrogado por normas publicisticas" RIVFRO, Jean. Direito Administrativo. Coimbra: Ehrardt Soares, Almedina. 1981. p. 494. Apud: DI PIETRO. Maria Sylvia Zanella. Direilo Administrativer. 14. cd. São Paulo: F.ditora Atlas, 2002. p. 98.

11. Idem Ibidem, p. 99. Mister salicntar que nesta definição. conforme avisa a autora. procura-se excluir a prestação jurisdicional e a legislaçăo do conceito de serviço público, considerando apenas as atividades administrativas sem distinguir o serviço público do poder de polícia, fomento e intervenção. Assim, restringe o conceito de serviço publico com o escopo de distingui-lo das outras trés atividades da Administraçào Pública.

113 Art. 175. Incumbe ao poder público, na forma de lei, diretamentc ou sob regime de concessão ou permıssão, sempre através de licitação, a prestação de serviços públicos.

114 DI PIETRO, Maria Sylvia Zanella. Direito Administrativo. 14. ed. Sào Paulo: Editora Atlas, 2002. p. 100.

115 "O serviço público, contrariamente à empresa privada, pode muito bem funcionar com prejuizo. Esta é mesmo uma das suas razōes de ser: incumbe-lhe satisłazer necessidades cuja não-rentabilidade afasta a empresa privada. Só a pessoa pública, por meio do imposto. pude transferir dos utentes para o conjunto das coletividades o financiamento do serviço". RIVERO, Jcan. Direito Administrativo. Coimbra: Ehrardt Soares, Almedina, 1981. p. 494. Apud: Idem Ibidem p. 101. "A gratuidade é, pois, a regra que prevalece em inúmeros serviços (ensino, assistência social, saúde); e. mesmo nos casos em que é exigida contribuição do usuário. ela pode ser inferior ao custo. Só no caso do serviço comercial e industrial é que a propria natureza da atividade exclui a gratuidade (transportes, água, energia elétrica) e a gestão tende. no mínimo. para um equilibrio e mesmo para um lucro que permita o auto-financiamento da cmpresa". Idem Ibidem, p. 101. 
Outra importante classificação í aquela que distingue serviços públicos próprios dos impróprios. Segundo José Cretella Júnior, ${ }^{116}$ esta classificação foi primeiramente proposta por Arnaldo de Valles e divulgada por Rafael Bielsa.

Tal classificação propugna que serviços públicos próprios são aqueles que o Estado assume e executa de forma direta ou indireta, de acordo com as necessidades coletivas envolvidas. Já os serviços públicos impróprios são aqueles que não são executados pelo Estado, embora seu objetivo também seja o interesse público.

No caso dos serviços públicos impróprios, o que ocorre é regulação e fiscalização estatal e, neste sentido, o adjetivo público seria impróprio, pois são exercidos por particulares, apenas estando sujeitos a uma ingerência do poder público.

Assim, aqui não haveria serviço público, mas mera atividade privada com fiscalização e regulamentação governamental. Assim, seria o caso dos serviços de táxi, de despachante, de pavimentação, de intermediação financeira, entre outros, não constituindo atividades públicas típicas. ${ }^{117}$

Aqui pretendemos excluir tais atividades do núcleo formador do critério material da hipótese de incidência das taxas, por não serem serviços públicos propriamente ditos.

\subsection{O Elemento Subjetivo e a Sujeição Ativa}

('omo vimos, na noção atual de serviço público, já se admite que terceiros exerçam tal atividade. Contudo, se o serviço for público, específico e divisivel, a contraprestação pecuniária se fará em forma de taxa, conforme já expusemos no capítulo anterior. Assim, teremos nova problemática: poderia o particular prestador de serviço público, nos termos da Constituição, utilizar tal modalidade exacional?

A maior parte da doutrina entende que isto é possível, designando o fenômeno como parafiscalidade. Neste sentido encontramos Roque Carrazza ${ }^{118}$ e Ataliba. ${ }^{119}$

116 CRETELLA JÚNIOR, José. Administração Indireta Brasileira. Rio de Janeiro: Forense, 1980. p. 50.

117 Hely Lopes Meirelles denomina este tipo de serviço de serviços públicos autorizados. Direiı Administrativo Brasileiro. São Paulc: Malheiros. 1996. p. 357.

118 Que afirma str a parafiscalidade: “(...) é a atribuição, pelo titular da competência tributária, mediante lei, de capacidade tributária ativa, a pessoas públicas ou privadas que persigam finalidades públicas ou de interesse público, diversas do ente imposto, que, por vontade desta mesma lei. passam a dispor do produto arrecadado, para a consecução dos seus objetivos". CARRAZA, Roque Antônio. U Sujeito Ativo da Obrigação Tributária. p. 40. Apuá ATALIBA. Geraldo. Hipótese de Incidenncia Triburária. 6. ed. São Paulo: Malhciros, 2001.p. 84.

119 Afirma: “A circunstância de o sujcito ativo não ser a própria entidade esıatal (União. Estado ou Municipio), mas outra pessoa designada pela lei - que arrccada o tributo em proveito das próprias linalidades - em nada altera o regime tributário, que deverá persistir sendo obsurvado" E acrescenta ainda: "Esta indicaçàu 
Lecionam ambos com acerto. De fato, a Constituição apenas elenca e distribui competència aos Estados-membros, Municípios, Distrito Federal e União, mas estes entes, se assim desejarem. podem delegar sua capacidade tributária ativa a uma autarquia, como acontece com o INSS, OAB, CEF entre outras. ou até mesmo para pessoas jurídicas de direito privado. ${ }^{120}$

Não-obstante, quando falamos de taxa, pode haver dupla delegação: a da prestação do serviço público (conforme art. 175 da Constituição) e da capacidade tributária ativa. Mas isto não é necessário, pois o Estado pode apenas terccirizar o serviço ou, se aprouver ao interesse público, apenas a cobrança.

O fato dos valores arrecadados por estas pessoas juridicas de direito privado integrar os cofres públicos posteriormente é indiferente, não desnatura a natureza jurídica nem da exação nem do serviço.

No caso em que o ente prestador do serviço público, de direito privado, preste o serviço e também recolhe a quantia contraprestacional, este deve ater-se ao regime jurídico tributário da figura e a todos os princípios e regras envolvidos. Neste sentido, ficam as concessionárias e permissionárias da prestação de serviço público específico e divisivel adstritas ao princípio da legalidade e da anterioridade em matéria tributária.

\subsection{A especificidade do Serviço Público}

Como já dissemos, para que haja a cobrança de taxa é necessário que o serviço seja específico. De fato, como já expusemos brevemente no histórico, quis o constituinte afastar cobranças absurdas de situações que não trazem nenhum benefĩcio direto ao contribuinte. Assim, os serviços públicos podem ser prestados de forma uti singuli ou uti universi, sendo aqueles os que têm por finalidade a satisfação individual e

explicita ou implicita, contida na lei tributária, da pessoa que irá ser sujeito ativo das obrigações nascidas dos fatos imponiveis. integra a h.i. e constitui seu aspecto pessoal, juntamente de determinação do sujeito passivo. Idem Ibidem, 2001. p. 85.

No mesmo sentido: "A prestação de serviço público é sempre taxa. O poder concedente não transfere para a concessionária a competência tributária, mas só a capacidade. Este arrecada a taxa com a qual deve manter a equação econômica-financeira do seu contrato de concessão, uma vez que isto the é garantido pela Constituição" LACOMBE, Américo Masset. Taxa e Preço Público. In: MARTINS, Ives Gandra da Silva. Caderno de Pesquisas Tributárias, n. 10, Temas: Taxa e Prę̧o Público. São Paulo: Resenha Tributária, 1985, p 22. Tambèm: "Não me parece que a expressão 'serviços públicos' só possa aplicar-se aos casos inerentes à atuação estatal soberana. Entendo que a locução atinge qualquer atividade compativel com a tutcla dos interesses coletivos a cargo dos entes públicos (...)". CANTO. Gilberto de Ulhôa. Idem. Ibidem, p. 103. 
direta das necessidades dos cidadãos è estes são aqueles prestados à coletividade, mas usufruídos apenas indiretamente pelos indivíduos. ${ }^{121}$

Isto posto, os serviços categorizados como uti universi não poderiam ensejar, de forma alguma, a cobrança de taxa (como taxa sobre iluminação pública e. no mesmo sentido, sobre conservação de parques e áreas públicas). Apenas us serviços prestados uti singuli dariam ensejo regular a esta cobrança.

\subsection{A alíquota e a base de cálculo}

Como já vimos, ambos compõe a endonorma da figura e a sincronia entre ambos formará, no momento oportuno, o quantum devido pelo contribuinte. Vimos também que o serviço público é forma de agir estatal, serviço eleito legalmente e posto sob a custódia do Estado para ser exercido por ele próprio ou por outro em seu nome.

Deste modo, a alíquota deve expressar um valor, correspondente à parcela de custo Estatal ou particular dispensada na prestação do serviço especifico. Não seria interessante admitir variações de aliquota em virtude da capacidade contributiva. Contudo. o que temos visto é a utilização da extrafiscalidade como técnica de coibir ou induzir utilização racional de serviço público. como acontece nas taxas de água e energia elétrica. conforme já analisamos.

De acordo com o elemento material do serviço público, este sempre servirá para uma finalidade pública, um interesse coletivo, que motivará o agir estatal naquela determinada área. Seria ilógico pretender-se lucro nestas circunstâncias, mesıno quando a atividade é exercida por particulares, já que o agir estatal é sempre motivador por um fim público maior, que prevalece sobre o individual privatístico no caso em tela.

Assim, a aliquota deve procurar exibir sempre o custo daquela unidade de serviço público específico. Por oportuno, sabemos que o custo de um determinado serviço não é determinado apenas pelos insumos e mão-de-obra envolvidos, mas também de acordo com a lógica do mercado (lei da oferta e da procura). sendo variável de acordo

1.. Conforme Maria Sylvia: "Serviços uti singuli são aqueles que têm por finalidade a satisfação individual e direta das necessidades dos cidadãos. Pelo conceito restrito de serviço público adotado por Celso Antonio Bandeira de Mello. só esta categoria constitui serviço públicu: prestação de utilidade ou comodidade fruivel diretamente pela comunidade. Entram nessa categoria deturminados serviços comerciais e industriais do Estado (energia elétrica, luz. gás. transportes) e de serviços sociais (ensino, saúde. assistência e previdência social).

Os serviços uti universi săo prestados à coletividade, mas usufruidos apenas indiretamente pelos individuos. É o caso dos serviços de defesa do pais contra o inimigo externo, dos serviços diplomáticos, dos serviços administrativos prestados internamente pela $\wedge$ dministração, dos trabalhos de pesquisa cientifica, de iluminação pública, de saneamento". DI PIETRO. Maria Sylvia Zanella. Direito .1dministrativo. 14. ed. São Paulo: Fditora Atlas, 2002. p. 105-106. 
com a situação econômica e de mercado verificada. Em virtude da incidência do principio da anterioridade e da legalidade, nem sempre o valor cobrado refletirá o custo efetivo. assim deve a administração valer-se de meios aproximativos e, se for o caso atuar deficitariamente, o que não-contraria a lógica do serviço público. ${ }^{122}$

Já a base de cálculo deve expressar a quantidade de serviço auferido pelo contribuinte. Daí a necessidade do serviço ser divisivel, pois caso contrário não se obedecerá à isonomia na tributação, cobrando quantias equivalentes para quem usufruiu o serviço em quantidades díspares. O serviço público indivisível, prestado de forma específica (ufi singuli) não puderá dar ensejo à cobrança de taxa, por expresso mandamento constitucional.

Não-obstante, um dos núcleos verbais da taxa propõe a cobrança mesmo nos casos cm que o serviço não é usufruído. Aqui deve haver a potencialidade em se usufruir o serviço, e ele. também neste caso, deve ser público, específico e divisível.

A potencialidade deve se referir, sempre à possibilidade do contribuinte, caso queira, usufruir imediatamente o serviço público específico e divisível. A prestação potencial deve estar sempre ao seu alcance, caso contrário, não pode a administração cobrar taxa.

Vejamos, por exemplo, na cobrança de taxa por utilização do serviço público, específico e divisível de fornecimento de água e esgoto. Aqui, deve o consumidor ter acesso à água, caso contrário a cobrança não se justifica. ${ }^{123}$ Contudo, verifícado tal acesso poderá haver cobrança mesmo que não haja consumo ou quando o consumo for mínimo.

Aqui, deve o legislador ater-se novamente à finalidade pública, que norteia a prestação dos serviços públicos. Neste sentido, assim como na formação da alíquota no caso de utilização concreta do serviço, a cobrança deve-se referir ao custo aproximado da

122 Vide nota 116 supra e citação respectiva.

123 "(...) é licita a cobrança da taxa de água pela tarifa minima, mesmo que haja hidrômetro que registre consumo inferior ao estabelecido. Tal conclusão foi tomada com base na interpretação da legislação que é aplicada a esse tipo de celação juriưica" Conforme entendimento em do Superior Tribunal de Justiça em Embargos de Declaração nos Émbargos de Declaraçào no Recurso Especial, EERESP n. 533.607 - RJ, Relator Ministro Josi Delgado, Primuira Turma, julgado um 01 de junho de 2004. publicado no Diário da Justiça em 05 de agosto de 2004.

E também, no mesmo sentido, conforme ementa: Administrativu. Serviço Público. Taxa de Água. Cobrança de Tarifa pelo Consumo Minimo. Legalidade. Precedentes Jurisprudenciais. É licita a cobrança da taxa de água pela tarifa minima, mesmo que haja hidrômetro yue registre consumo inferior àquele. Inteligência das disposições legais que regulam a fixação tarifária (ant. 4, da Lei n. $6.528 / 78$ e ants. 11 caput, $11, \S 2^{\circ}$ e 32 do Decreto n. 82.587/78). Recurso provido. Fontc: Superior Tribunal de Justiça em Recuso Especial, RESP n. 525.500 - AL. Relatora Ministra Eliana Calnon. Segunda Turma. julgado en 16 de dezembro de 2003, publicado no Diário da Justiça em 16 de dezembro de 2003.

Aqui verilicamos que o valor contraprestacional se refere não só a quantidade (que nestes casos furam inferior ao mínimo). mas a potencialidade de utilização, o que por si sỏ já dá ensejo à cohrança. 
manutenção do serviço e das estruturas necessárias a sua prestação continuada, no intuito de garantir a potencialidade.

\section{C'onclusões}

A partir do quanto supra-assinalado concluímos:

1. Taxa é uma espécie de tributu que se caracteriza como uma contraprestação a serviço público específico e divisivel diretamente destinado ao contribuinte.

I.I. A natureza pública deste surviço é verificada através de três elementos: (i) subjetivo; (ii) material; (iii) formal.

1.2. A sua especificidade pela presença da característica ut singuli do serviço.

1.3. A divisibilidade diz respeito à possibilidade de separar o quantum auferido pelo serviço em unidades.

2. A cobrança desta taxa pode ser efetuada: (i) quando utilizado serviço público específico e divisível ou (ii) estc é posto à disposição.

3. A base de cálculo das taxas de serviço corresponde ao quantum de serviço público usufruido e, no caso de serviço posto à disposição. ao custo de manutenção desta disponibilidade.

4. A alíquota corresponde ao custo do serviço, por unidade divisível.

5. Rejeita-se a aplicação da capacidade contributiva nesse tipo de exação, mas permanece a possibilidade de aplicar-se a ıxtrafiscalidade, desde que respeitados os limites constitucionais para at sua imposição.

6. É possível a sua cobrança por meio de entidades privadas (parafiscalidade), sem que seu regime juridico tributário seja afetado.

São Paulo, dezembro de 2005.

Referências

ALMIRO, Afonso. Vormas Gerais de Direitu Financeiro. Rio de Janeiro: Instituto Brasileiro de Direito Financciro, 1950.

AMARU, Luciano. Direito Tributário Brasileiro. São Paulo: Saraiva, 1997.

ANIDO. Miguel Angel Caamaño. Concurrenia de Tasas y Capacidad Contributiva. Revista de Direito Tributário. São Paulo, v. 15. n. 58, p. 90-98, out./dez. 1991.

AT ALIBA, Geraldo. Hipótese de Incidência Tributária. 6. ed. São Paulo: Malheiros, 2001. 
BALEEIRO. Aliomar. Limitações Constitucionais ao Poder de Trihutar. Rio de Janeiro: Forense, 1997.

Uma Introdução à Ciência das Fianças. 5. ed. Rio de Janciro: Forense, 1968.

BECKER, Alfredo Augusto. Teoria Geral do Direito Trihutário. 3. ed. São Paulo: Lejus, 1999.

BOTALlO, Eduardo. Capacidade Contributiva. Revista de Direito Tributurio, n. 47.

CAMPOS, Francisco. Direito Constitucional. São Paulo: Ed. Freitas Bastos, 1956. v. II.

CANTO, Gilberto Ulhôa. Temas de Direito Tributário. Rio de Janeiro: Editora Alba, 1964.

CARVALHO, Paulo de Barros. Teoria da Norma Tributária. 3. ed. São Paulo: Max Limonad, 1998. . Curso de Dircito Tributário. 14. ed. São Paulo: Saraiva, 2002.

CARRIÓ, Genaro. Notas sobre derecho y lenguaje. Buenos Aires : Abeledo-Perrot, 1972.

CAVALCANTI, Amaro. Flementos de Finanças. Rio de Janeiro: Imprensa Nacional, 1986.

CORREIA, Érica Paula Barcha. A natureza jurídica das contribuições sociais. Revista de Previdência Social. L Tr, São Paulo, ano 22, n. 216, p. 943-952, nov. 1998.

CORREIA, Marcus Orione Gonçalves. Da natureza jurídica das contribuições previdenciárias. Revista das Faculdades Integradas Toledo, Araçatuba, v. 2, n. I, p. 68-74, jun. 1999.

CRETELLA JINIOR, José. Administração Indireta Brusileira. Rio de Janeiro: Forense, 1980. . As cláusulas "de privilégio" nos contratos administrativos. Revista da Procuradoria Geral do Estado, Porto Alegre, v. 17, n. 45, p. 27-46, 1987.

DAI LARI, Adilson Abreu. ('ontrato de Obra Pública. ('adernos FUNDAP São Paulo, ano 5, n. 11, 1985.

DI PIETRO, Maria Sylvia Zanella. Direito Administrativo. 14. ed. São Paulo: Fditora Atlas, 2002. Do Direito Privado na Administração Pública. São Paulo: Editora Atlas, 1989.

FALCÃO, Amilcar de Araújo. Introdução ao Direito Tributärio. Rio de Janeiro: Edições Financeiras, 1959.

FANUCCHII, Fábio. Reforma Constitucionul Tributária. São Paulo: Editora Atlas, 1966.

FERR1Z IR., Tércio Sampaio. Função Social da Dogmática Juridica. São Paulo: Max Limonad. 1998. 
FERRAZ JR., Tércio Sampaio. Princípio da Igualdade no Sistema Tributário, conferência proferida em curso promovido pelo Instituto Internacional de Direito Público e Empresarial ¿ Tribunal Regional Federal da 3." Região. Revista de Direito Tributário, São Paulo, v. 15, n. 58. p. 200-226, out./dez., 1991.

GARCIA, Evaristo. A Tuxa nos Sistemas Tributários dos Municipios. São Paulo: edição do autor, 1943.

GIANNINI, Achille Donato. I concetti fondamentali del Diritto Tributario. Turim: UET, 1956.

GRECO. Marco Aurélio. Contribuições (uma figura “sui generis"). São Paulo: Dialética, 2000.

LÔBO, Ubaldo (ct al). Anais da I Conferência de Técnicos em Contabilidade Pública e Assuntos Fazendários. Rio de Janciro: Ministério da Fazenda, 1940.

MACHADO, Hugo de Brito. Os Principios Juridicos da Tributação na constituição de 1988. São Paulo: Dialética. 2001.

MARTINS, Ives Gandra da Silva (Org.). Caderno de Pesquisas Tributárias. n. 10, Temas: Taxa e Preço Público. São Paulo: Resenha Tributária. 1985.

Teoria da Imposição Tributária. 3. ed. São Paulo: LTr, 1998.

MAYNEZ, Eduardo (jarcia. Intoducción al estudio Del derecho. 18. ed. México, 1971.

MEIRA, Silvio. Direito Tributário Romano. São Paulo: Revista dos Tribunais, 1978.

MEIRELLES, Hely Lopus. Direito Administrativo Brusileiro. São Paulo: Malheiros, 1996.

MELLO, Celso Antônio Bandeira de. O Contezido Juridico do Principio da Igualdade. 3. ed. São Paulo: Malheiros, 1999.

Prestação de Serviços Públicos e Administração Indirela. São Paulo: Revista dos Tribunais, 1975.

MORAES, Bernardo Ribeiro de. A Taxa no Sistema Tributário Brasilciro. São Paulo: Revista dos Tribunais, 1968 .

NOGUliRA, Ruy Barbosa. Da interpretação e da aplicação das leis tributárias. 2. ed. São Paulo: Revista dos Tribunais, 1965.

Princípios e Conceitos Científicos da Tributação, como Pressupostos para a Lugislação e para a Interpretação e Aplicação do Direito Tributário. Revista Dialética de Direito Tributário, São Paulo, n. 36, p. 95-105, set. 1998. 
NOVEI LI. Flávio Bauer. Apontamentos sobre o Conceito Jurídico de Taxa. Revista de Direito Administrativo. n. 189. jul.'set.. 1992.

OFFE, Claus. Capitalismo De'sorganizado. São Paulo: Brasiliense, 1995.

ROCHA, Valdir de Oliveira (Coord.). Grandes Quesıôes Atuais de Direito Trihutário. São Paulo: Dialética, 2003.

SABINE M.A. A Short Histury of Taxution. I.ondon: Butterworths, 1980.

SÃO VICENTF, José Antònio Pimenta Bueno, Marquês de. Direilo Público Brasileiro e Análise da Constituição do Império. Rio de Janeiro: Edição do Ministério da Justiça e Negócios Interiores Serviço de Documentação. 1958.

SCHOUERI, Luís Eduardo. ('ontribuição ao Estudo do Regime Juridico das Normas Tributárias Indutoras como Instrumentu subre o Dominio Fconómico, Tese de Titularidade. São Paulo: Faculdade de Direito da LSP. 2003.

(Coord.). Direito Tributario em Homenagem a Alcides Jorge Costa. São Paulo: Quartier Latin, 2002.

SOUZA, Rubens Gomes de. Compêndio de Legislação Tributária. 2.ed. São Paulo: Edições Financeiras. 1954.

O. Vovo Sistema Trihutário Nacional. São Paulo: Assnciação dos Advogados de São Paulo, 1967.

Trubalhus da Comissão Especial do Código Tributário Vacional. Rio de Janciro: Ministério da Fazenda, 1954.

SOUZA, Ruy de. ('iencia das Finanças. Belo Horizonte: Faculdade de Direitu da Universidade de Minas Gerais, 1953.

TÔRRES. Heleno Taveira. Funções das luis complementares no sistema tributário nacional hicrarquia de normas - papel do Código Tributário Nacional no ordenamento. Revisıa de Direito Tributário, São Paulo, n. 84, p. 50-69. 2002.

Substituição tributária: regime constitucional, classificação e relações jurídicas (materiais : processuais). Revista Dialérica de Direito Tribulário, São Paulo, n. 70, p. 87-108, jul. 2001.

TORRES, Ricardo I obo. C'urso de Direiro Financeiro. Rio de Janeiro: Renovar. 1999.

ZIL.VFTI, Fernando Aurélio. Principios de Direito Tributcirio e a Capacidade Contributiva. São Paulo: Quartier Latin. 2004. 